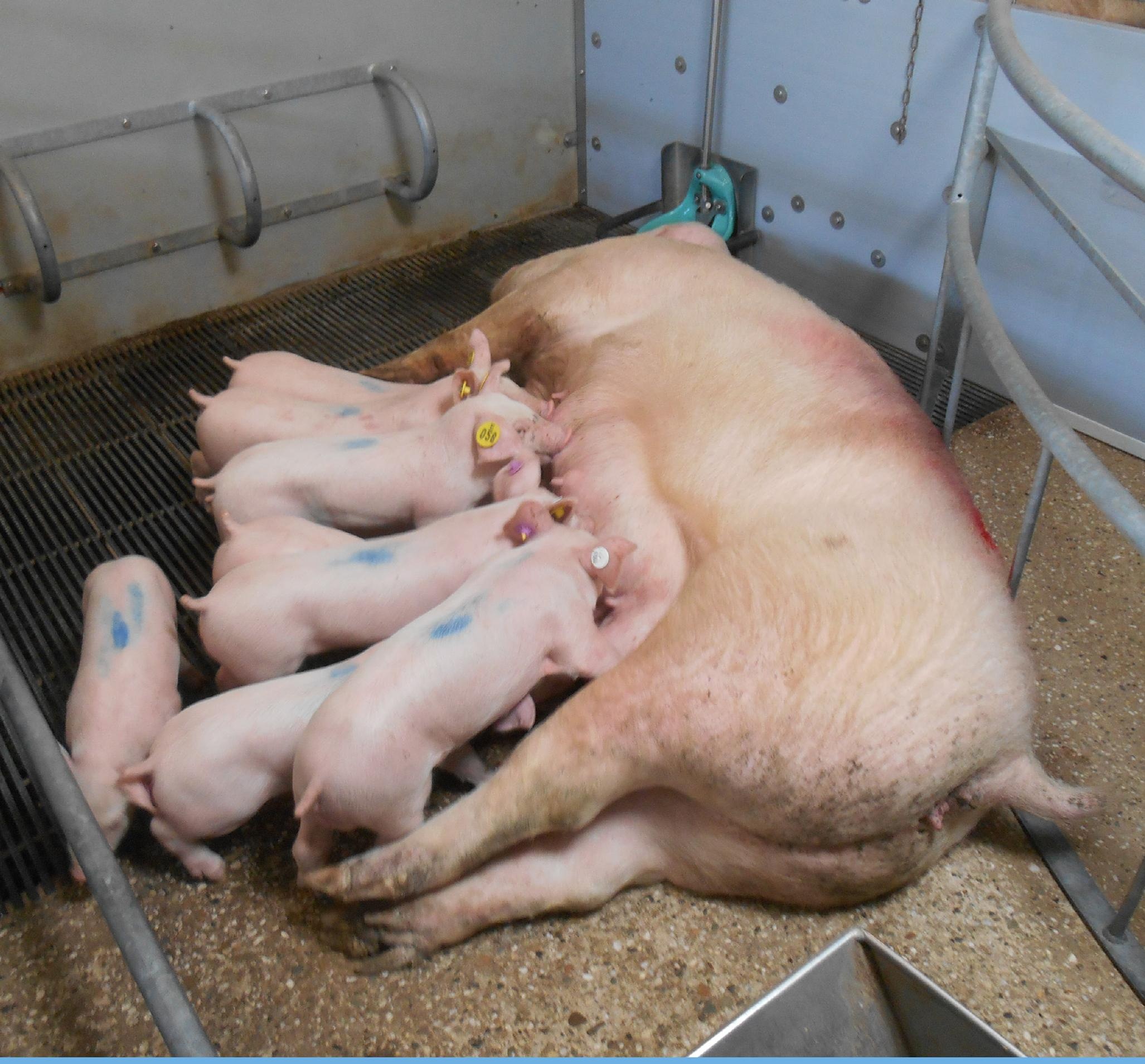

Effect van voersamenstelling bij drachtige lacterende zeugen en voerniveau begin dracht op reproductie en conditie 


\section{Effect van voersamenstelling bij drachtige lacterende zeugen en voerniveau begin dracht op reproductie en conditie}

Effect of feed composition in gestating lactating sows and feeding level during early gestation on reproduction and condition

C.M.C. van der Peet-Schwering ${ }^{1}$, R. Verheijen ${ }^{1}$, G.P. Binnendijk ${ }^{1}$, N.M. Soede ${ }^{2}$

${ }^{1}$ Wageningen UR Livestock Research

${ }^{2}$ Wageningen Universiteit, leerstoelgroep Adaptatiefysiologie

Dit onderzoek is uitgevoerd als onderdeel van de publiek-private samenwerking (PPS) "Feed4Foodure", en is medegefinancierd door het Ministerie van Economische Zaken, in het kader van het Beleidsondersteunend Onderzoek (projectnummer BO31.03-005-001).

Wageningen UR Livestock Research

Wageningen, mei 2016 
C.M.C. van der Peet-Schwering, R. Verheijen, G.P. Binnendijk, N.M. Soede, 2016. Effect van voersamenstelling bij drachtige lacterende zeugen en voerniveau begin dracht op reproductie en conditie; Effect of feed composition in gestating lactating sows and feeding level during early gestation on reproduction and condition. Wageningen, Wageningen UR (University \& Research centre) Livestock Research, Livestock Research Rapport 952. 48 blz.

Samenvatting NL: Op VIC Sterksel is onderzocht wat het effect is van een zetmeelrijk versus een vetrijk voer tijdens de laatste 8 dagen van een 6-weekse lactatie waarin de zeugen ook drachtig zijn op de gewichts- en spekdikte ontwikkeling van de zeugen, de technische resultaten van de biggen en het aantal levend en dood geboren biggen in de volgende worp. Daarnaast is nagegaan wat het effect is van een hoger voerniveau vanaf spenen (ca. 9 dagen na inseminatie) tot 34 dagen dracht op de gewichts- en spekdikte ontwikkeling van de zeugen tijdens de dracht en het aantal levend en dood geboren biggen in de volgende worp. De resultaten van het onderzoek zijn in dit rapport beschreven.

Trefwoorden: drachtige lacterende zeug, voersamenstelling, intermittent suckling, voerniveau, reproductie, groei biggen

Keywords: gestating lactating sow, feed composition, intermittent suckling, feeding level, reproductive performance, daily gain piglets

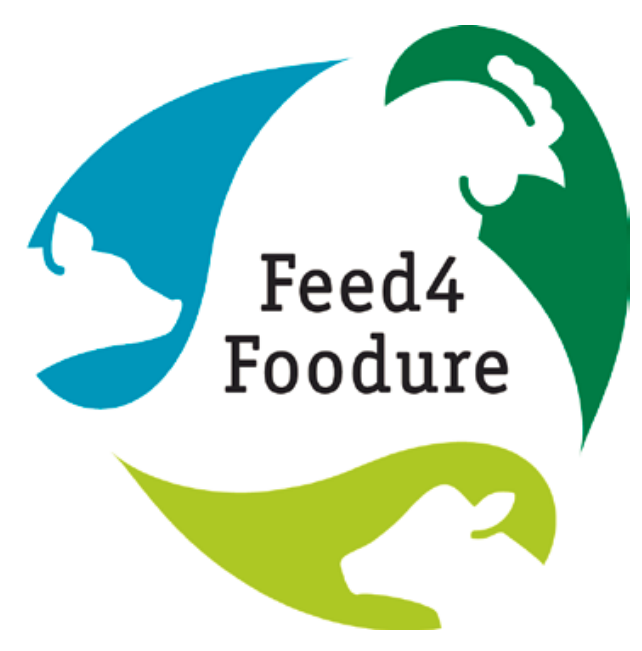

(C) 2016 Wageningen UR Livestock Research, Postbus 338, 6700 AH Wageningen, T 03174839 53, E info.livestockresearch@wur.nl, www.wageningenUR.nl/livestockresearch. Livestock Research is onderdeel van Wageningen UR (University \& Research centre).

Livestock Research aanvaardt geen aansprakelijkheid voor eventuele schade voortvloeiend uit het gebruik van de resultaten van dit onderzoek of de toepassing van de adviezen.

Alle rechten voorbehouden. Niets uit deze uitgave mag worden vermenigvuldigd en/of openbaar gemaakt worden door middel van druk, fotokopie, microfilm of op welke wijze dan ook zonder voorafgaande toestemming van de uitgever of auteur.

De certificering volgens ISO 9001 door DNV onderstreept ons kwaliteitsniveau. Op als onze onderzoeksopdrachten zijn de Algemene Voorwaarden van de Animal Sciences Group van toepassing. Deze zijn gedeponeerd bij de Arrondissementsrechtbank Zwolle. 


\section{Inhoud}

$\begin{array}{ll}\text { Woord vooraf } & 5\end{array}$

$\begin{array}{ll}\text { Samenvatting } & 7\end{array}$

$\begin{array}{ll}\text { Summary } & 9\end{array}$

\begin{tabular}{lr}
1 & 1 Inleiding \\
\hline
\end{tabular}

$2 \quad$ Materiaal en methode $r 12$

2.1 Proeflocatie en proefomvang 12

2.2 Proefbehandelingen $\quad 12$

2.3 Proefopzet en werkwijze 12

$\begin{array}{lll}2.4 & \text { Huisvesting } & 13\end{array}$

2.5 Voeding en drinkwaterverstrekking $\quad 14$

$\begin{array}{ll}2.6 & \text { Waarnemingen } \\ 2.7 & 15\end{array}$

$\begin{array}{lll}2.7 & \text { Gegevensverwerking en statistische analyse } & 16\end{array}$

$\begin{array}{lll}3.1 & \text { Samenstelling van de voeders } & 17\end{array}$

$\begin{array}{lll}3.2 & \text { Huidige worp } & 17\end{array}$

3.2.1 Voeropname, gewicht en spekdikte van de zeugen $\quad 17$

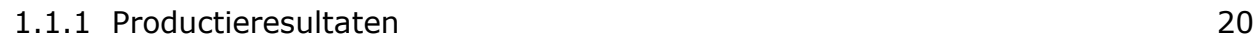

3.2.2 Reproductieresultaten $\quad 22$

3.2.3 Melkmonsters en progesteron $\quad 23$

$\begin{array}{ll}3.2 .4 & \text { Diarreescores biggen } \\ & 25\end{array}$

$\begin{array}{lll}3.3 & \text { Volgende worp } & 27\end{array}$

3.3.1 Voeropname, gewicht en spekdikte van de zeugen $\quad 27$

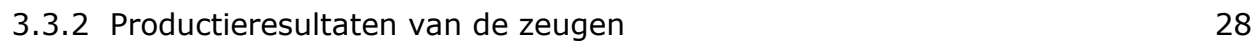

$\begin{array}{lll}3.4 & \text { Relaties } & 29\end{array}$

$\begin{array}{llr}4 & \text { Discussie } & 30\end{array}$

$5 \quad$ Conclusies $\quad 35$

$\begin{array}{ll}\text { Literatuur } & 36\end{array}$

Bijlage 1 Grondstoffen (\%)- en nutriënten samenstelling van de proefvoeders

Bijlage 2 Voeropname zeugen per pariteit 39

$\begin{array}{lll}\text { Bijlage } 3 \text { Gewicht en spekdikte per pariteit } & 40\end{array}$

Bijlage 4 Gewicht- en spekdikte afname per pariteit 41

Bijlage $5 \quad$ Productieresultaten per pariteit $\quad 42$

$\begin{array}{lll}\text { Bijlage } 6 & \text { Resultaten zuigende biggen per pariteit } & 43\end{array}$

Bijlage 7 Gewicht en spekdikte per pariteit in de volgende worp 44

Bijlage 8 Productieresultaten per pariteit in de volgende worp 46

$\begin{array}{lll}\text { Bijlage } 9 & \text { Relaties } & 47\end{array}$ 


\section{Woord vooraf}

Het onderzoek "Effect van voersamenstelling bij drachtige lacterende zeugen en voerniveau begin dracht op reproductie en conditie" is uitgevoerd als onderdeel van de PPS Feed4Foodure, project MVV2 "Voeding van zeugen in welzijnsgerichte systemen". De auteurs bedanken de opdrachtgevers voor de financiële ondersteuning van het onderzoek. Daarnaast bedanken de auteurs de afgevaardigden van de mengvoerindustrie in het projectteam Erik Bruininx (Agrifirm), Torsten Köhler (ForFarmers), Albert Timmerman (De Heus) en Pieter Langendijk (Nutreco) voor hun waardevolle en inspirerende inhoudelijke bijdrage aan het onderzoek. Tot slot bedanken de auteurs de dierverzorgers van VIC Sterksel voor de goede uitvoering van de proef en Bjorge Laurenssen van Wageningen Universiteit voor het scannen van de zeugen.

Carola van der Peet-Schwering

Projectleider 


\section{Samenvatting}

$\mathrm{Er}$ is weinig bekend over de voeding van zeugen die zowel drachtig als lacterend zijn tijdens een verlengde lactatie. In een onderzoek op Varkens Innovatie Centrum Sterksel is daarom nagaan wat het effect is van een zetmeelrijk versus een vetrijk lactatievoer tijdens de laatste 8 dagen van een 6weekse lactatie waarin de zeugen ook drachtig zijn op de gewichts- en spekdikte ontwikkeling van de zeugen, de technische resultaten van de biggen en het aantal levend en dood geboren biggen in de volgende worp. Daarnaast is nagegaan wat het effect is van een hoger voerniveau vanaf spenen (ca. 9 dagen na inseminatie) tot 34 dagen dracht op de gewichts- en spekdikte ontwikkeling van de zeugen en het aantal levend en dood geboren biggen in de volgende worp. Gedurende 7 ronden zijn elke drie weken 15 zeugen (pariteit 2-7) van het kruisingstype $\mathrm{Y}$ beer $\times \mathrm{NI}$ zeug ingezet in het onderzoek. Een week voor werpen werden de zeugen in de kraamstal geplaatst. Op dag 27 van de lactatie is gestart met intermittent suckling (IS), waarbij de zeugen, gedurende een periode van 7 dagen, 10 uur per dag van de biggen werden gescheiden. De biggen zijn op dag 27 overgeplaatst naar zoogopfokhokken waarin ze als toom tot spenen gehuisvest bleven. De zeugen werden gedurende de ISperiode dagelijks om $6.00 \mathrm{u}$ 's ochtends overgebracht naar de dekstal waar ze als groep werden gehouden in voerligboxen met uitloop. Om $16.00 \mathrm{u}$ 's middags werden ze verplaatst naar hun biggen in de zoog-opfokhokken. In de dekstal is twee keer per dag de berigheid van de lacterende zeugen gecontroleerd door een zoekbeer voor de boxen langs te laten lopen. 24 uur na de eerste stareflex werden de zeugen geïnsemineerd. $\mathrm{Na}$ inseminatie is geen IS meer toegepast en bleven de zeugen tot spenen bij de biggen in de zoog-opfokhokken. Tot dag 34 van de lactatie kregen alle zeugen hetzelfde lactovoer verstrekt. Vanaf dag 34 tot spenen op dag 42 kregen de zeugen een zetmeelrijk of een vetrijk lactovoer verstrekt. Vanaf spenen (ca. 9 dagen na inseminatie) t/m 34 dagen dracht kregen de zeugen $2,8 \mathrm{~kg} / \mathrm{d}$ (standaard voerniveau) of $3,5 \mathrm{~kg} / \mathrm{d}$ (hoog voerniveau) drachtvoer.

De belangrijkste conclusies uit het onderzoek zijn:

Zetmeelrijk versus vetrijk lactovoer tijdens laatste 8 dagen van de 6-weekse lactatie:

- Van de 103 zeugen die ingezet zijn in het onderzoek zijn er 79 (is 76,7\%) binnen 6 dagen na start van IS berig geworden. Dit percentage was vergelijkbaar bij de zeugen die daarna het zetmeelrijke of vetrijke lactovoer kregen.

- Van de 79 zeugen die geïnsemineerd zijn, waren er 65 (is 82,3\%) drachtig vier weken na inseminatie. Dit percentage was vergelijkbaar bij de zeugen die het zetmeelrijke of vetrijke lactovoer kregen.

- $\quad$ Tijdens de laatste 8 dagen van de 6-weekse lactatie was er een tendens tot minder gewichtsverlies bij de zeugen op het zetmeelrijke voer ( 9 versus $13 \mathrm{~kg} ; \mathrm{p}=0,11$ ). Het speengewicht en de groei en de voeropname van de biggen tijdens de laatste 8 dagen van de 6-weekse zoogperiode waren vergelijkbaar bij de zeugen die het zetmeelrijke of het vetrijke lactovoer kregen.

- De melkproductie van de zeugen bleef tijdens de laatste 8 dagen van de 6-weekse lactatie op een hoog niveau van ca. $11 \mathrm{~kg} / \mathrm{d}$.

- $\quad$ Er waren tussen de zeugen die het zetmeelrijke of vetrijke lactovoer kregen geen significante verschillen in de gehalten aan droge stof, ruw eiwit, vet en lactose in de melk op de dag van spenen. Er waren wel verschillen in de vetzuursamenstelling.

- Het progesterongehalte in de melk van de drachtige zeugen tendeerde naar hoger bij de zeugen die het zetmeelrijke lactovoer kregen $(16,2$ versus $15,3 \mathrm{ng} / \mathrm{ml} ; \mathrm{p}=0,07)$.

- $\quad$ Bij de biggen van de zeugen op het vetrijke voer kwam meer diarree voor tijdens de laatste 8 dagen van de 6-weekse lactatie dan bij de biggen van de zeugen op het zetmeelrijke voer.

Het totaal aantal geboren biggen en het aantal levend en dood geboren biggen in de volgende worp verschilden niet significant tussen de zeugen die het zetmeelrijke of vetrijke lactovoer kregen. Het geboortegewicht van de biggen was numeriek, maar niet significant, hoger bij de zeugen die het zetmeelrijke lactovoer kregen (1,35 versus $1,27 \mathrm{~kg} ; \mathrm{p}=0,12)$. 
Hoog versus standaard voerniveau vanaf spenen tot 34 dagen dracht:

- Het percentage drachtige zeugen vier weken na inseminatie was hoger bij de zeugen die op het hoge voerniveau werden gevoerd tot 34 dagen dracht dan bij de zeugen die op het standaard voerniveau werden gevoerd.

- Van spenen op dag 42 na werpen tot inzet kraamstal namen de zeugen op het hoge voerniveau meer toe in gewicht dan de zeugen op het standaard voerniveau $(67,8$ versus $59,0 \mathrm{~kg} ; \mathrm{p}=0,01)$. Er was geen duidelijk verschil in spekdikte toename tussen de zeugen op het hoge of standaard voerniveau $(4,5$ versus $4,1 \mathrm{~mm} ; \mathrm{p}=0,29)$.

- Het totaal aantal geboren biggen, het aantal levend en dood geboren biggen en het geboortegewicht van de biggen verschilde niet significant tussen de zeugen die een hoog of standaard voerniveau kregen tot 34 dagen dracht.

Overall kan geconcludeerd worden dat zeugen tijdens de laatste 8 dagen van een 6-weekse zoogperiode waarin ze ook drachtig zijn op een hoog voerniveau gevoerd moeten worden. Ter vermindering van het gewichtsverlies van de zeugen heeft een zetmeelrijk lactovoer de voorkeur boven een vetrijk lactovoer. Daarnaast zorgt een hoog voerniveau $(3,5 \mathrm{~kg} / \mathrm{d}$ ) van spenen tot 34 dagen dracht voor een beter conditieherstel tijdens de dracht dan het standaard voerniveau $(2,8 \mathrm{~kg} / \mathrm{d})$. 


\section{Summary}

There is little information about the feeding of sows that are both gestating and lactating during an extended lactation. Therefore, at Swine Innovation Centre Sterksel, the effect of feeding sows that are both gestating and lactating a starch rich or a fat rich lactation diet during the last 8 days of a 6 -week lactation on weight and backfat thickness, performance of the piglets and the number of live born and stillborn piglets in the next parity were studied. In addition, the effect of feeding level from weaning (about 9 days after insemination) until day 34 of gestation on weight and backfat thickness and the number of live born and stillborn piglets in the next parity was studied. During a 5-month period, 105 (7 batches of 15 sows) Y $x$ NL sows (parity 2-7) were allotted to the experiment. One week before farrowing sows were moved to farrowing pens. On day 27 of lactation intermittent suckling (IS) started to induce lactational estrus. During a period of 7 days, sows and piglets were separated for 10 hours per day. At the start of IS on day 27 , piglets were moved to lactation-rearing pens in which they were housed as a litter until weaning. Sows were moved to free access stalls in the mating stable at $6.00 \mathrm{~h}$. At $16.00 \mathrm{~h}$ they were moved to their piglets in the suckling-rearing pens. In the mating room estrus was checked twice a day in the presence of a mature boar. Sows that showed estrus were inseminated each day of standing estrus. After insemination, IS was no longer applied and sows remained with their piglets until weaning on day 42 after farrowing. Until day 34 of lactation, all sows were fed the same lactation diet. From day 34 until day 42 sows were fed a starch rich or a fat rich diet lactation diet. From weaning (about 9 days after insemination) until day 34 of gestation sows were fed $2.8 \mathrm{~kg} / \mathrm{d}$ (standard feeding level) or $3.5 \mathrm{~kg} / \mathrm{d}$ (high feeding level) of a commercial gestation diet.

The main conclusions of the experiment are:

Starch rich versus fat rich lactation diet during the last 8 days of a 6-week lactation:

- 79 of the 103 sows (is $76.7 \%$ ) showed estrus within 6 days after the start of IS. This percentage was similar in sows that were fed the starch rich or the fat rich diet.

- 65 of the 79 inseminated sows (is $82.3 \%$ ) were pregnant four weeks after insemination. Pregnancy percentage was similar in sows that were fed the starch rich or the fat rich diet during the last 8 days of the six-week lactation.

- Weight loss ( 9 versus $13 \mathrm{~kg} ; \mathrm{p}=0.11$ ) during the last 8 days of the 6 -week lactation tended to be lower in the sows that were fed the starch rich diet.

- Weaning weight of the piglets and feed intake and growth of the piglets during the last 8 days of the 6-week lactation period was similar in sows fed the starch rich or the fat rich diet.

- The milk production of the sows stayed at a high level of about $11 \mathrm{~kg} / \mathrm{d}$ during the last 8 days of the 6-week lactation.

- At weaning the milk composition of the sows was measured. The levels of dry matter, crude protein, fat and lactose in the milk were similar in sows fed the starch rich or the fat rich diet. The fatty acid composition differed between sows fed the starch rich or the fat rich diet.

- Progesterone level in the milk of the sows that were pregnant four weeks after insemination tended to be higher in the sows fed the starch rich diet $(16.2$ versus $15.3 \mathrm{ng} / \mathrm{ml} ; \mathrm{p}=0.07$ ).

- The occurrence of diarrhea during the last 8 days of the 6-week lactation was higher in piglets from sows that were fed the fat rich diet.

- The number of total born, live born and stillborn piglets in the next litter was similar in the sows that were fed the starch rich or the fat rich diet during the last 8 days of the previous 6week lactation. The birth weight of the live born piglets was numerically, but not significant, higher in sows fed the starch rich diet (1.35 versus $1.27 \mathrm{~kg} ; \mathrm{p}=0.12)$. 
High versus standard feeding level from weaning until day 34 of gestation:

- The percentage of pregnant sows four weeks after insemination was higher in sows that were fed the high feeding level until day 34 of gestation.

- Body weight gain from weaning until the day of transfer to the farrowing room was higher in sows that were fed the high feeding level until day 34 of gestation $(67.8$ versus $59.0 \mathrm{~kg} ; \mathrm{p} \mathrm{=}$ 0.01 ). The gain in backfat thickness from weaning until the day of transfer to the farrowing room was similar in sows fed the high or the standard feeding level until day 34 of gestation (4.5 versus $4.1 \mathrm{~mm} ; \mathrm{p}=0.29$ ).

- The number of total born, live born and stillborn piglets and the birth weight of the live born piglets was similar in the sows that were fed the standard or high feeding level until day 34 of gestation.

Overall it can be concluded that sows that are both gestating and lactating during a 6-week lactation period should be fed on a high feeding level. To reduce the loss of body weight, a starch rich diet is preferred over a fat rich diet. A high feeding level $(3.5 \mathrm{~kg} / \mathrm{d})$ after weaning until day 34 of gestation results in a better condition recovery of the sows than a standard feeding level ( 2.8 $\mathrm{kg} / \mathrm{d})$. 


\section{Inleiding}

Vanuit de PPS Samenwerkende varkenshouderijketen wordt een groepshuisvestingssysteem voor kraamzeugen en haar biggen ontwikkeld tot een commercieel toepasbaar huisvestingssysteem. In dit systeem worden de biggen later gespeend en worden de zeugen geïnsemineerd tijdens de verlengde lactatie. Om de berigheid van de zeugen tijdens de lactatie te stimuleren wordt intermittent suckling (IS) toegepast. Dit betekent dat de zeug en haar biggen gedurende een aantal dagen circa 10 uren per dag van elkaar gescheiden worden. De zeugen worden na circa 5 dagen berig en kunnen dan worden geïnsemineerd. De vraag is hoe deze zeugen, zowel tijdens de verlengde lactatie waarin ze ook drachtig zijn als in de eerste periode na spenen, gevoerd moeten worden.

In 2013 is een literatuurstudie uitgevoerd naar de voeding van lacterende zeugen in welzijnsvriendelijke huisvestingssystemen met een verlengde lactatie en inseminatie tijdens de lactatie (Rommers et al., 2014). Hieruit bleek dat er weinig bekend is over de voeding van zeugen die zowel drachtig als lacterend zijn tijdens een verlengde lactatie. In 2014 is door Van der Peet-Schwering et al. (2015) een onderzoek uitgevoerd naar het voerniveau van zeugen gedurende de laatste 8 dagen van een 6 -weekse lactatie (hoog $(6,5 \mathrm{~kg})$ versus laag $(4,0 \mathrm{~kg})$ voerniveau), waarin ze ook drachtig zijn. Het effect op de gewichts- en spekdikte ontwikkeling van de zeugen tijdens de verlengde lactatie en de daarop volgende dracht, het percentage zeugen dat afbigt van eerste inseminatie en het aantal levend en dood geboren biggen in de volgende worp is onderzocht. Uit dit onderzoek bleek dat de zeugen op het lage voerniveau veel gewicht $(23 \mathrm{~kg}$ ) verloren in de laatste 8 dagen van de lactatie en dat ze minder biggen wierpen in de volgende worp (11,5 versus 14,1 levend geboren biggen) dan de zeugen op het hoge voerniveau. De zeugen op het hoge voerniveau verloren echter ook $14 \mathrm{~kg}$ in de laatste 8 dagen van de lactatie. Mogelijk verliezen de zeugen minder gewicht als ze op een nog hoger voerniveau gevoerd worden en als ze een voer krijgen met een hoger zetmeelgehalte (Van den Brand et al., 2000a). Uit onderzoek van Van den Brand et al. (2000a) bleek nl. dat zeugen gevoerd op een hoog voerniveau met een zetmeelrijk voer tijdens een 3-weekse lactatie minder gewicht verloren dan zeugen gevoerd op een hoog voerniveau met een vetrijk voer. Het aantal levend geboren biggen in de volgende worp daarentegen wordt mogelijk positief beïnvloed door een hoger vetgehalte in het voer omdat een hoog vetgehalte in het voer tijdens de vroege dracht de progesteron productie verhoogt op dag 15 van de dracht (Athorn et al., 2013).

Uit het onderzoek van Van der Peet-Schwering et al. (2015) bleek tevens dat de zeugen niet in conditie herstelden tijdens de dracht die volgde op de 6-weekse lactatie. Van inzet kraamstal tot inzet kraamstal in de volgende worp namen zowel de zeugen op het hoge als lage voerniveau af in gewicht en spekdikte. Dit komt mogelijk omdat ze op het standaard voerschema zijn gevoerd in de drachtstal en geen extra voer kregen om te compenseren voor het gewichtsverlies tijdens de 6-weekse lactatie. Als de zeugen op een hoger voerniveau worden gevoerd tijdens de eerste maand van de dracht, herstellen ze mogelijk wel in conditie. Dit verkleint mogelijk het risico op embryonale sterfte.

Doel van het onderzoek was nagaan wat het effect is van een zetmeelrijk versus een vetrijk lactatievoer bij een hoog voerniveau tijdens de laatste 8 dagen van een 6 -weekse lactatie waarin de zeugen ook drachtig zijn, op: 1) de conditie (gewichts- en spekdikte ontwikkeling) van de zeugen; 2) de gewichtsontwikkeling en voeropname van de biggen tijdens de verlengde lactatie; 3 ) het percentage drachtige zeugen en het percentage zeugen dat afbigt van eerste inseminatie; 4) het aantal levend en dood geboren biggen in de volgende worp en het geboortegewicht van de levend en dood geboren biggen. Daarnaast is nagegaan wat het effect is van een hoger voerniveau vanaf spenen (ca. 9 dagen na inseminatie) tot 34 dagen dracht op de gewichts- en spekdikte ontwikkeling van de zeugen tijdens de dracht en het aantal levend en dood geboren biggen in de volgende worp. Het onderzoek is uitgevoerd met zeugen die individueel gehuisvest waren tijdens de lactatie. 


\section{Materiaal en methode}

\subsection{Proeflocatie en proefomvang}

Het onderzoek is uitgevoerd op Varkens Innovatie Centrum (VIC) Sterksel in de periode maart 2015 tot en met januari 2016 met in totaal 105 oudereworps (pariteit 2-7) zeugen van het kruisingstype $Y$ beer $x$ Nl zeug. Gedurende 7 ronden werden elke drie weken 15 zeugen ingezet in het onderzoek. Eersteworps zeugen zijn niet ingezet vanwege de mogelijk lagere kans op berig worden. Oude zeugen (> pariteit 7) zijn niet meegenomen vanwege mogelijk tegenvallende toomgrootte. De zeugen zijn gevolgd vanaf inzet in de kraamstal tot en met spenen van de volgende worp.

\subsection{Proefbehandelingen}

In het onderzoek zijn vier proefbehandelingen met elkaar vergeleken in een $2 \times 2$ factoriële proef:

1) Zetmeelrijk voer lactatie, standaard voerniveau dracht: deze zeugen zijn na inseminatie tijdens de 6-weekse lactatie op een hoog voerniveau $(=7,5 \mathrm{~kg} / \mathrm{zeug} / \mathrm{dag}=8,1 \mathrm{EW} / \mathrm{zeug} / \mathrm{dag})$ gevoerd met een zetmeelrijk lactovoer; van inzet in de drachtstal (ca. 9 dagen na inseminatie) t/m 34 dagen dracht kregen ze 2,8 kg standaard drachtvoer per dag.

2) Zetmeelrijk voer lactatie, hoog voerniveau dracht: deze zeugen zijn na inseminatie tijdens de 6 -weekse lactatie op een hoog voerniveau $(=7,5 \mathrm{~kg} / \mathrm{zeug} / \mathrm{dag}=8,1 \mathrm{EW} / \mathrm{zeug} / \mathrm{dag})$ gevoerd met een zetmeelrijk lactovoer; van inzet in de drachtstal t/m 34 dagen dracht kregen ze 3,5 $\mathrm{kg}$ drachtvoer per dag.

3) Vetrijk voer lactatie, standaard voerniveau dracht: deze zeugen zijn na inseminatie tijdens de 6 -weekse lactatie op een hoog voerniveau ( $=6,9 \mathrm{~kg} / \mathrm{zeug} / \mathrm{dag}=8,1 \mathrm{EW} / \mathrm{zeug} / \mathrm{dag}$ ) gevoerd met een vetrijk lactovoer; van inzet in de drachtstal t/m 34 dagen dracht kregen ze 2,8 kg drachtvoer per dag.

4) Vetrijk voer lactatie, hoog voerniveau dracht: deze zeugen zijn na inseminatie tijdens de 6weekse lactatie op een hoog voerniveau $(6,9 \mathrm{~kg} / \mathrm{zeug} / \mathrm{dag}=8,1 \mathrm{EW} / \mathrm{zeug} / \mathrm{dag})$ gevoerd met een vetrijk lactovoer; van inzet in de drachtstal t/m 34 dagen dracht kregen ze 3,5 kg drachtvoer per dag.

Vanaf inzet kraamstal tot inseminatie tijdens de 6-weekse lactatie zijn alle lacterende zeugen in de proef volgens hetzelfde voerschema en met hetzelfde lactovoer gevoerd (zie 2.5).

\subsection{Proefopzet en werkwijze}

Een week voor werpen werden de zeugen in de kraamstal geplaatst. Op dag 21 van de lactatie werden 15 zeugen per ronde toegewezen aan de voerbehandeling (alternerend 8 en 7 zeugen voor respectievelijk zetmeelrijk en vetrijk voer) op basis van pariteit, gewicht en spekdikte bij inzet in de kraamstal en het aantal biggen in een toom op dag 21.

Op dag 27 van de lactatie (woensdag) werd gestart met intermittent suckling (IS), waarbij de zeugen, gedurende een periode van 7 dagen, 10 uur per dag van de biggen werden gescheiden. De biggen werden op dag 27 overgeplaatst naar zoog-opfokhokken waarin ze als toom tot spenen gehuisvest bleven. De zeugen werden gedurende de IS-periode dagelijks om $6.00 \mathrm{u}$ 's ochtends overgebracht naar de dekstal waar ze als groep werden gehouden in voerligboxen met uitloop. Om $16.00 \mathrm{u}$ 's middags werden ze verplaatst naar hun biggen in de zoog-opfokhokken. In de dekstal werd twee keer per dag ( $9.00 \mathrm{u}$ en $15.00 \mathrm{u}$ ) de berigheid van de lacterende zeugen gecontroleerd door een zoekbeer voor de boxen langs te laten lopen. 24 uur na de eerste stareflex werden de zeugen geïnsemineerd met een commerciële KI dosis (Tempo met ca. $2.5 \times 10^{9}$ spermacellen) en 24 uur later werden ze, indien nodig, nog een keer geïnsemineerd. Na inseminatie werd geen IS meer toegepast en bleven de zeugen tot spenen bij de biggen in de zoog-opfokhokken. Zeugen die niet berig werden binnen 7 dagen na aanvang IS zijn gevolgd tot spenen maar niet meer tijdens de daarop volgende dracht. Op dag 34 van de lactatie (woensdag) is gestart met de voerbehandeling en kregen de zeugen tot spenen op dag 42 (donderdag) een zetmeelrijk of een vetrijk voer verstrekt. 
De dag voor spenen zijn zowel de zeugen op het zetmeelrijke als het vetrijke voer op basis van pariteit, gewicht en spekdikte evenredig verdeeld over het standaard en het hoge voerniveau tijdens de dracht.

\section{$2.4 \quad$ Huisvesting}

\section{Kraamstal}

Een week voor werpen werden de zeugen naar de kraamstal verplaatst. De zeugen en biggen waren tot dag 27 na werpen gehuisvest in de kraamstal. De kraamafdelingen hadden elk 12 hokken. De kraamhokken waren 1,80 m breed en 2,40 m diep. De vloer bestond vanaf de voergang gezien uit een geplastificeerd rooster van $1,85 \mathrm{~m}$ diep en een metalen driekant rooster van 0,55 $\mathrm{m}$. Het vloergedeelte onder de zeug was $0,65 \mathrm{~m}$ breed. In alle kraamafdelingen kwam de verse lucht binnen via een verlaagde luchtinlaat onder de mestpannen.

\section{Zoog-opfokhokken}

Op dag 27 na werpen werden de zeugen en hun biggen verplaatst naar zoog-opfokhokken. De zoogopfokhokken waren groter dan de kraamhokken en de zeug kon los lopen. De 15 zoog-opfokhokken bevonden zich in twee afdelingen. De zes zoog-opfokhokken in afdeling 1 waren 2,10 m breed en 2,65 $\mathrm{m}$ diep. De vloer bestond uit 1,15 $\mathrm{m}$ dichte betonvloer en 1,50 $\mathrm{m}$ betonrooster. De negen zoogopfokhokken in afdeling 2 waren 2,39 m breed en 3,25 m diep. De vloer bestond uit 2,05 m dichte betonvloer en 1,20 $\mathrm{m}$ betonrooster. De zeugen uit de twee proefbehandelingen werden evenredig verdeeld over de twee afdelingen. In de zoog-opfokhokken was de voertrog voor de zeug op een zodanige hoogte aangebracht dat de biggen er niet bij konden.

\section{Dekstal tijdens IS}

In de dekstal waren de zeugen gehuisvest in één groep in 15 naast elkaar liggende voerligboxen met uitloop. De voerligboxen waren 2,00 m lang en 0,60 m breed. De vloer bestond vanaf de voergang gezien uit 1,52 m dichte betonvloer en vervolgens uit 0,48 m metalen driekant rooster. De uitloop achter de boxen was $2,00 \mathrm{~m}$. De zeugen werden vanaf verplaatsen naar de dekstal (om $6.00 \mathrm{u}$ 's ochtends) tot na de bronstcontrole (om 9.30 u 's ochtends) vastgezet in de voerligboxen. Om $9.30 \mathrm{u}$ werden ze losgelaten. 's Middags tijdens de bronstcontrole van 15.00 tot 16.00 u werden ze opnieuw vastgezet in de voerligboxen om vervolgens verplaatst te worden naar de zoog-opfokhokken. Tijdens de berigheid werden de zeugen opgesloten in de voerligboxen.

\section{Drachtstal}

Bij spenen op dag 42 waren de zeugen 8 tot 10 dagen drachtig. De zeugen zijn als groep verplaatst naar een drachtafdeling met voerligboxen met uitloop. De groep werd hierbij opgesplitst in twee subgroepen (subgroep van 4 tot 8 zeugen op het hoge voerniveau en subgroep van 4 tot 8 zeugen op het standaard voerniveau). De drachtafdeling bestond uit 84 voerligboxen met uitloop. Een subgroep werd gehuisvest in twee rijen van tegenover elkaar liggende voerligboxen met daar tussenin een uitloop van 2,40 m betonrooster of metalen driekant rooster. De voerligboxen waren 0,72 $\mathrm{m}$ breed en 2,30 m diep. De vloer in de ligboxen bestond uit 2,00 $\mathrm{m}$ dichte beton vloer en 0,30 $\mathrm{m}$ betonrooster of metalen driekant rooster. Een week voor de te verwachte werpdatum werden de zeugen verplaatst naar de kraamstal. 


\subsection{Voeding en drinkwaterverstrekking}

\section{Kraamstal}

In de kraamstal kregen de zeugen standaard lactovoer $(E W=1,08$; ruw vet $=56 \mathrm{~g} / \mathrm{kg}$; zetmeel = $364 \mathrm{~g} / \mathrm{kg}$ ) verstrekt. De zeugen werden tweemaal daags gevoerd ('s ochtends tussen 8.00 en $10.00 \mathrm{u}$ en 's middags tussen 15.30 en 17.30 uur) volgens het standaard voerschema van VIC Sterksel. Voor het werpen kregen de zeugen $3,25 \mathrm{~kg}$. Na werpen is de voergift geleidelijk verhoogd tot maximaal 7,5 $\mathrm{kg}$ voer per dag tot de start van IS. Drinkwater was onbeperkt beschikbaar via een drinknippel in de trog.

De zuigende biggen werden vanaf dag 2 na geboorte bijgevoerd. Viermaal daags kregen ze creepfeed $(E W=1,32 ;$ ruw eiwit $=174 \mathrm{~g} / \mathrm{kg}$; darmverteerbaar lysine $=11,7 \mathrm{~g} / \mathrm{kg})$ verstrekt. Vanaf dag 17 werd geleidelijk (in twee dagen) overgeschakeld op speenvoer ( $E W=1,12$; ruw eiwit $=153 \mathrm{~g} / \mathrm{kg}$; darmverteerbaar lysine $=9,85 \mathrm{~g} / \mathrm{kg}$ ). Vanaf dag $20 \mathrm{kregen}$ de biggen alleen speenvoer gevoerd. Het voer werd verstrekt in een rond bijzetbakje. Drinkwater stond onbeperkt ter beschikking via een drinknippel.

\section{Zoog-opfokhokken en dekstal}

Tijdens de IS periode (dag $27 \mathrm{t} / \mathrm{m} 33$ na werpen) kregen de zeugen maximaal 7,5 kg standaard lactovoer verstrekt. De zeugen werden 's ochtends om ca. $8.00 \mathrm{u}$ in de dekstal gevoerd en 's middags om ca. $17.30 \mathrm{u}$ in de zoog-opfokhokken, nadat de biggen hadden gezoogd. Zowel 's ochtends als 's middags kregen ze de helft van de dagelijks te verstrekken hoeveelheid voer. In de dekstal werden de zeugen individueel gevoerd in voerligboxen. Tijdens het voeren waren ze opgesloten in de boxen. Een half uur na het voeren werd genoteerd hoeveel voer er nog in de troggen lag (veel-matig-weinig). Het voer werd vervolgens verwijderd uit de troggen om te voorkomen dat andere zeugen dit opaten. De voergift 's middags werd (indien nodig) bijgesteld als de zeugen 's ochtends niet al het voer hadden opgegeten.

Vanaf dag 34 na werpen tot spenen op dag 42 kreeg de helft van de zeugen een zetmeelrijk lactatievoer $(E W=1,08$; zetmeel $=415 \mathrm{~g} / \mathrm{kg} ;$ rvet $=40 \mathrm{~g} / \mathrm{kg}$ ) verstrekt en de andere helft van de zeugen een vetrijk lactatievoer $(\mathrm{EW}=1,18$; zetmeel $=325 \mathrm{~g} / \mathrm{kg}$; rvet $=96 \mathrm{~g} / \mathrm{kg}$ ). De zeugen op beide voeders werden isocalorisch gevoerd en kregen dagelijks dezelfde hoeveelheid eiwit, darmverteerbare aminozuren, mineralen en vitamines verstrekt. Alleen de verstrekte hoeveelheden zetmeel en ruw vet verschilden tussen de twee voerbehandelingen. De zeugen op het zetmeelrijke lactatievoer kregen dagelijks maximaal 7,5 kg voer ofwel 8,1 EW verstrekt. De zeugen op het vetrijke lactatievoer kregen dagelijks maximaal 6,9 kg voer ofwel 8,1 EW verstrekt. De grondstoffen- en nutriëntensamenstelling van het zetmeelrijke en vetrijke lactatievoer is weergegeven in bijlage 1 .

De zeugen werden 's ochtends om ca. $8.00 \mathrm{u}$ en 's middags om ca. $16.00 \mathrm{u}$ handmatig gevoerd. Zowel 's ochtends als 's middags kregen ze de helft van de dagelijks te verstrekken hoeveelheid voer. De biggen konden niet mee eten uit de trog van de zeug. Drinkwater stond onbeperkt ter beschikking via een drinknippel in de trog.

De biggen kregen onbeperkt speenvoer verstrekt via een rond bijzetbakje gedurende de eerste 6 dagen in de zoogopfokhokken (alleen wanneer de zeug in de dekstal was; anders at de zeug het voer mogelijk op) en via een 4-vaks droogvoerbak. Vanaf dag 34 na werpen tot spenen werd het voer alleen verstrekt via een 4-vaks droogvoerbak. De voerbak was zodanig opgesteld dat de zeug er niet uit kon eten. Drinkwater was onbeperkt ter beschikking via een drinknippel in het hok.

\section{Drachtstal}

Na spenen op dag 42 na werpen kregen de zeugen standaard drachtvoer $(E W=1,03$; ruw eiwit = 119 $\mathrm{g} / \mathrm{kg}$ ). De zeugen op het standaard voerniveau kregen $\mathrm{t} / \mathrm{m} 34$ dagen dracht $2,8 \mathrm{~kg} / \mathrm{d}$, de zeugen op het hoge voerniveau $3,5 \mathrm{~kg} / \mathrm{d}$. De zeugen werden tweemaal daags (ca. $8.00 \mathrm{u}$ en ca. $15.00 \mathrm{u}$ ) gevoerd. De eerste week in de drachtstal zijn de zeugen rond het voeren gedurende een uur vastgezet. Daarna werden ze niet meer vastgezet rond het voeren. Het voerschema zag er als volgt uit: 


\begin{tabular}{lcc}
\hline & Standaard voerniveau & Hoog voerniveau \\
& $(\mathrm{kg} / \mathrm{d})$ & 5,0 \\
\hline Dag van inzet drachtstal (donderdag) & 5,0 & 3,5 \\
Dag 1 na inzet t/m 34 dagen dracht (is 25 dagen & 2,8 & \\
na inzet drachtstal) & & 3,1 \\
Dag 35 dracht & 2,7 & 2,7 \\
Dag 36 t/m dag 75 & 2,7 & 3,0 \\
Dag 76 en 77 & 3,0 & 3,25 \\
Dag 78 tot inzet kraamstal & 3,25 & \\
\hline
\end{tabular}

Drinkwater was onbeperkt beschikbaar via drinkbakjes in het hok.

\subsection{Waarnemingen}

De volgende waarnemingen zijn uitgevoerd bij de dieren.

- Gewicht bij inzet in de kraamstal, bij start IS, bij start voerbehandeling, bij spenen, bij inzet in de kraamstal van de volgende worp en bij spenen van de volgende worp.

- Spekdikte bij inzet in de kraamstal, bij start IS, bij start voerbehandeling, bij spenen, op dag 28 en dag 77 van de dracht en bij inzet in de kraamstal en spenen van de volgende worp. De spekdikte is bepaald op de P2-plaats (ter hoogte van de laatste rib, $6 \mathrm{~cm}$ links en rechts van de mediaan).

- Voeropname per zeug van inzet in de kraamstal tot werpen, van werpen tot start IS, van start IS tot start voerbehandeling en van start voerbehandeling tot spenen.

- Voeropname tijdens de dracht per zeug van inzet drachtstal t/m 34 dagen dracht en van dag 35 dracht tot inzet kraamstal.

- Scannen van de zeugen bij start IS en op 5 dagen na start IS om te bepalen in welke mate follikelontwikkeling heeft plaats gevonden. Bij het scannen zijn de vijf grootste follikels opgemeten (in $\mathrm{mm}$ ) en is het aantal follikels geteld tot een maximum van 10. Bij meer dan 10 follikels is 10 genoteerd. Omdat in het onderzoek van Van der Peet-Schwering et al. (2015) enkele zeugen op dag 16 terugkwamen zijn in het huidige onderzoek de zeugen op de dag van de spenen nogmaals gescand om inzicht te krijgen of ze geövuleerd hebben.

- Datum berigheid, inseminatiedatum en afbigpercentage van $1^{\text {ste }}$ inseminatie. Op vier weken na inseminatie zijn de zeugen uitwendig gescand op dracht.

- Op de dag van spenen is een melkmonster van ca. $40 \mathrm{ml}$ genomen bij de zeugen. De melk werd opgevangen in potjes en tot analyse bewaard in de diepvries. In alle melkmonsters zijn de gehalten aan droge stof, vet, eiwit en lactose bepaald. Daarnaast is het progesterongehalte bepaald in alle melkmonsters. Het progesterongehalte is bepaald via enzym immunoassay (Ridgeway Science Ltd., Gloucestershire, UK) zoals beschreven door Roelofs et al. (2006). In 14 gepoolde melkmonsters (per ronde per voersamenstelling tijdens de lactatie zijn de melkmonsters gepoold) is de vetzuursamenstelling bepaald.

- Aantal levend en dood geboren biggen en geboortegewicht van de levend en doodgeboren biggen in de huidige en de volgende worp.

- Aantal biggen en gewichten van de biggen bij start IS, bij start voerbehandeling en bij spenen van de huidige worp.

- Voeropname van de biggen van geboorte tot start IS, van start IS tot start voerbehandeling en van start voerbehandeling tot spenen.

- Uitval van biggen en zeugen en veterinaire behandelingen werden vastgelegd.

- Diarreescores bij de biggen zijn tweemaal per week uitgevoerd vanaf de dag voor start IS tot spenen. De scores werden op dinsdag en donderdag uitgevoerd, in totaal 6 keer. Er werd een inschatting gemaakt van het aantal dieren met harde mest, normale mest, pasteuze mest en waterdunne mest. Daarnaast is de kleur van de mest beoordeeld (gelige mest, grijze mest of zwarte/bruine mest).

- Tijdens de productie van de voeders zijn voermonsters genomen. De voeders zijn in twee keer geproduceerd. De vier voermonsters ( $2 \times$ zetmeelrijk voer en $2 \times$ vetrijk voer) zijn geanalyseerd 
op de Weende analyse componenten (droge stof, as, ruwe celstof, ruw eiwit, ruw vet, zetmeel en suiker).

\subsection{Gegevensverwerking en statistische analyse}

Alle gegevens zijn geanalyseerd met behulp van SAS (2013).

De gewichten, spekdikten en voeropname van de zeugen, de follikelgrootte op dag 0 , dag 5 en bij spenen, de follikelgroei van dag 0 tot dag 5 , de grootte van de corpora lutea bij spenen, de melkmonsters en het aantal levend en dood geboren biggen zijn op dierniveau geanalyseerd met behulp van variantie analyse. De gewichten en voeropname van de biggen zijn op toomniveau geanalyseerd met variantie analyse. Het percentage berige zeugen is geanalyseerd met logistische regressie. Het model dat gebruikt is voor de analyses zag er als volgt uit:

$\mathrm{Y}=\mathrm{u}+$ ronde + pariteit + voersamenstelling + interacties + rest

Pariteit was als volgt in klassen ingedeeld: pariteit $2,3+4$ en $5+6+7$ in de huidige worp.

Het percentage drachtige zeugen is geanalyseerd met logistische regressie. Voerniveau tijdens de dracht en de interactie tussen voersamenstelling tijdens de lactatie en voerniveau tijdens de dracht zijn als factor toegevoegd aan het model. Het model zag er als volgt uit:

$\mathrm{Y}=\mathrm{u}+$ ronde + pariteit + voersamenstelling + voerniveau tijdens de dracht + interacties + rest

Bij de analyse van het gewicht en de spekdikte van de zeugen in de volgende worp en van het totaal aantal geboren biggen, het aantal levend en dood geboren biggen en het geboortegewicht van de levend geboren biggen in de volgende worp is voerniveau tijdens de dracht als factor toegevoegd aan het model en de interactie tussen voersamenstelling tijdens de lactatie en voerniveau tijdens de dracht. Ronde is niet opgenomen in het model omdat het aantal zeugen dat per ronde geworpen heeft van eerste inseminatie relatief klein was. De genoemde kenmerken zijn op dierniveau geanalyseerd met behulp van variantie analyse met het volgende model:

$\mathrm{Y}=\mathrm{u}+$ pariteit + voersamenstelling + voerniveau tijdens de dracht + interacties + rest

Bij de analyse van het geboortegewicht van de levend geboren biggen is het aantal levend geboren biggen als covariabele opgenomen in het model.

Diarreescores (zowel consistentie als kleur) zijn geanalyseerd met het drempelmodel van McCullagh (Oude Voshaar, 1994).

Daarnaast zijn de volgende relaties geanalyseerd:

- $\quad$ Relatie gewicht en spekdikte bij start voerbehandeling en gewichts- en spekdikteverlies tijdens de laatste 8 dagen van de zoogperiode met groei en voeropname van de biggen in deze periode.

- $\quad$ Relatie gewichts- en spekdikteverlies tijdens de hele zoogperiode en tijdens de laatste 8 dagen van de zoogperiode met totaal aantal geboren biggen, aantal levend geboren biggen in de volgende worp en geboortegewicht van de levend geboren biggen. 


\section{Resultaten}

Er zijn 105 zeugen ingezet in het onderzoek; 53 zeugen kregen na inseminatie tijdens de 6-weekse lactatie een zetmeelrijk voer verstrekt en 52 zeugen een vetrijk voer. In de zetmeel groep is één zeug voortijdig uit de proef gehaald omdat de zeug heel slecht wilde eten. In de vetgroep is één zeug gestorven. Beide zeugen zijn niet meegenomen in de resultaten.

\subsection{Samenstelling van de voeders}

In tabel 1 zijn de vooraf berekende en achteraf geanalyseerde gehalten aan droge stof, as, ruwe celstof, ruw eiwit, ruw vet, zetmeel en suiker in het zetmeelrijke en vetrijke lactovoer weergegeven.

Tabel 1

Berekende en geanalyseerde gehalten aan droge stof, as, ruwe celstof, ruw eiwit, ruw vet, zetmeel en suiker $(\mathrm{g} / \mathrm{kg})$ in het zetmeelrijke en vetrijke lactovoer.

\begin{tabular}{lcccc}
\hline & \multicolumn{2}{c}{ Zetimeelrijk lactovoer } & \multicolumn{2}{c}{ Vetrijk lactovoer } \\
\hline Derekend & geanalyseerd & berekend & geanalyseerd \\
As & 882 & 886 & 888 & 895 \\
Ruwe celstof & 57 & 54 & 63 & 59 \\
Ruw eiwit & 49 & 44 & 55 & 48 \\
Ruw vet & 137 & 137 & 150 & 154 \\
Zetmeel & 40 & 40 & 96 & 84 \\
Suiker & 415 & 420 & 326 & 316 \\
\hline
\end{tabular}

Uit tabel 1 blijkt dat in het zetmeelrijke lactovoer de berekende en geanalyseerde gehalten goed met elkaar overeen komen. In het vetrijke voer is het geanalyseerde vetgehalte iets lager dan het vooraf berekende vetgehalte. De overige berekende en geanalyseerde gehalten komen goed met elkaar overeen.

\subsection{Huidige worp}

\subsubsection{Voeropname, gewicht en spekdikte van de zeugen}

De voeropname van de zeugen in de kraamstal is per voerbehandeling weergegeven in tabel 2 . In bijlage 2 is de voeropname per pariteit en per voerbehandeling per pariteit (pariteit 2, pariteit $3+4$ en pariteit $5+6+7$ ) weergegeven.

Uit tabel 2 blijkt dat de voeropname van de zeugen tot start voerbehandeling op dag 34 na werpen vergelijkbaar was. Vanaf start voerbehandeling tot spenen was er geen duidelijk verschil in voer- en EW-opname tussen de zeugen op het zetmeelrijke of vetrijke voer. In beide groepen was de EWopname lager dan de geplande opname van 8,1 EW/d. Dit komt m.n. door zeven zeugen (vier op het zetmeelrijke voer en drie op het vetrijke voer) met een voeropname van minder dan 3,4 kg tijdens de laatste 8 dagen van de lactatie. Als deze zeven zeugen niet meegenomen worden is de EW-opname van de zeugen van start voerbehandeling tot spenen respectievelijk 7,52 en 7,62 EW/d ( $p=0,67)$ op het zetmeelrijke en vetrijke voer. $\mathrm{Er}$ is geen duidelijk aanwijsbare reden waarom deze zeven zeugen weinig voer hebben opgenomen. 


\section{Tabel 2}

Voeropname $(\mathrm{kg} / \mathrm{d})$ zeugen tijdens de 6-weekse lactatie; tot start voerbehandeling op dag 34 na werpen kregen alle zeugen hetzelfde lactovoer; daarna kregen de zeugen tot spenen op dag 42 een zetmeelrijk of vetrijk lactovoer verstrekt.

\begin{tabular}{|c|c|c|c|c|}
\hline & \multicolumn{2}{|c|}{ Voersamenstelling } & \multirow[t]{2}{*}{$S E M^{1}$} & \multirow[t]{2}{*}{ P-waarde } \\
\hline & zetmeelrijk & vetrijk & & \\
\hline Aantal zeugen & 52 & 51 & & \\
\hline Worpnummer & 4,3 & 4,3 & & \\
\hline \multicolumn{5}{|l|}{ Voeropname (kg/dag): } \\
\hline - inleg kraamhok tot werpen & 2,72 & 2,73 & 0,028 & 0,89 \\
\hline - werpen tot start IS & 6,29 & 6,19 & 0,075 & 0,37 \\
\hline - start IS tot start voerbehandeling & 5,91 & 6,16 & 0,125 & 0,15 \\
\hline - start voerbehandeling tot spenen & 6,51 & 6,23 & 0,214 & 0,35 \\
\hline $\begin{array}{l}\text { - start voerbehandeling tot spenen } \\
\text { (EW-opname/d) }\end{array}$ & 7,03 & 7,35 & 0,238 & 0,35 \\
\hline
\end{tabular}

${ }^{1}$ SEM $=$ gepoolde standaard error van het gemiddelde

De gewichts- en spekdikte ontwikkeling van de zeugen in de kraamstal zijn weergegeven in tabel 3. De gewichten en spekdikte per pariteit en per behandeling per pariteit (pariteit 2, pariteit $3+4$ en pariteit $5+6+7$ ) zijn weergegeven in bijlage 3 . Voor geen enkel kenmerk was er sprake van een significante interactie tussen voerbehandeling en pariteit. De gewichts- en spekdikte afname van inzet kraamstal tot start IS, van start IS tot start voerniveau en van start voerniveau tot spenen zijn weergegeven in respectievelijk figuur 1 en 2.

\section{Tabel 3}

Gewichten en spekdikten van de zeugen tijdens de 6-weekse lactatie; tot start voerbehandeling op dag 34 na werpen kregen alle zeugen hetzelfde lactovoer; daarna kregen de zeugen tot spenen op dag 42 een zetmeelrijk of vetrijk lactovoer verstrekt.

\begin{tabular}{|c|c|c|c|c|}
\hline & \multicolumn{2}{|c|}{ Voersamenstelling } & \multirow[t]{2}{*}{$S E M^{1}$} & \multirow[t]{2}{*}{ P-waarde } \\
\hline & zetmeelrijk & vetrijk & & \\
\hline Aantal zeugen & 52 & 51 & & \\
\hline \multicolumn{5}{|l|}{ Gewicht $(\mathrm{kg})$ : } \\
\hline - bij inleg kraamhok & 267 & 266 & 2,5 & 0,77 \\
\hline - bij start IS op dag 27 & 222 & 223 & 2,3 & 0,85 \\
\hline - bij start voerbehandeling op dag 34 & 223 & 226 & 2,6 & 0,41 \\
\hline - bij spenen op dag 42 & 212 & 213 & 2,5 & 0,78 \\
\hline \multicolumn{5}{|l|}{ Spekdikte $(\mathrm{mm})$ : } \\
\hline - bij inleg kraamhok & 15,8 & 15,6 & 0,36 & 0,80 \\
\hline - bij start IS op dag 27 & 12,2 & 12,3 & 0,34 & 0,93 \\
\hline - bij start voerbehandeling op dag 34 & 11,3 & 11,3 & 0,34 & 0,90 \\
\hline - bij spenen op dag 42 & 10,7 & 10,4 & 0,31 & 0,60 \\
\hline
\end{tabular}

${ }^{1} \mathrm{SEM}=$ gepoolde standaard error van het gemiddelde

Uit tabel 3 blijkt dat bij de start van de voerbehandeling op dag 34 na werpen en bij spenen op dag 42 na werpen de zeugen op het zetmeelrijke en vetrijke voer een vergelijkbaar gewicht hadden. De gewichtsafname van de zeugen van start voerbehandeling tot spenen was eveneens vergelijkbaar bij het zetmeelrijke en het vetrijke voer (respectievelijk 11 en $13 \mathrm{~kg} ; \mathrm{p}=0,34$; figuur 1 ). Het totale gewichtsverlies van inzet kraamstal tot spenen was bij de zeugen op het zetmeelrijke voer $55 \mathrm{~kg}$ en op het vetrijke voer $53 \mathrm{~kg}$ ( $p=0,52$; figuur 1 ). Als de zeven zeugen (vier op het zetmeelrijke voer en drie op het vetrijke voer) met een voeropname van minder dan 3,4 kg tijdens de laatste 8 dagen van de lactatie niet meegenomen worden in de resultaten zijn de gewichten bij start voerbehandeling respectievelijk 222 en $226 \mathrm{~kg}(p=0,31)$ op het zetmeelrijke en vetrijke voer en bij spenen 
respectievelijk 213 en $213 \mathrm{~kg}(p=0,80)$. De gewichtsafname van start voerbehandeling tot spenen is respectievelijk 9 en $13 \mathrm{~kg}(p=0,11)$ op het zetmeelrijke en vetrijke voer.

De spekdikte bij de start van de voerbehandeling op dag 34 na werpen en bij spenen op dag 42 na werpen was vergelijkbaar bij de zeugen op het zetmeelrijke en vetrijke voer. De zeugen op het zetmeelrijke voer verloren van start voerniveau tot spenen $0,6 \mathrm{~mm}$ spek, de zeugen op het vetrijke voer $0,9 \mathrm{~mm}(p=0,14$; figuur 2$)$. Van inzet kraamstal tot spenen verloren de zeugen op het zetmeelrijke voer $5,1 \mathrm{~mm}$ spek en de zeugen op het vetrijke voer 5,2 mm ( $p=0,79$; figuur 2 ). Als de zeven zeugen (vier op het zetmeelrijke voer en drie op het vetrijke voer) met een voeropname van minder dan $3,4 \mathrm{~kg}$ tijdens de laatste 8 dagen van de lactatie niet meegenomen worden in de resultaten zijn de spekdiktes bij start voerbehandeling respectievelijk 11,2 en 11,4 mm $(p=0,69)$ op het zetmeelrijke en vetrijke voer en bij spenen respectievelijk 10,6 en $10,6 \mathrm{~mm}(p=0,88)$. De spekdikte afname van start voerbehandeling tot spenen is respectievelijk 0,6 en $0,8 \mathrm{~mm}(p=0,12)$ op het zetmeelrijke en vetrijke voer.

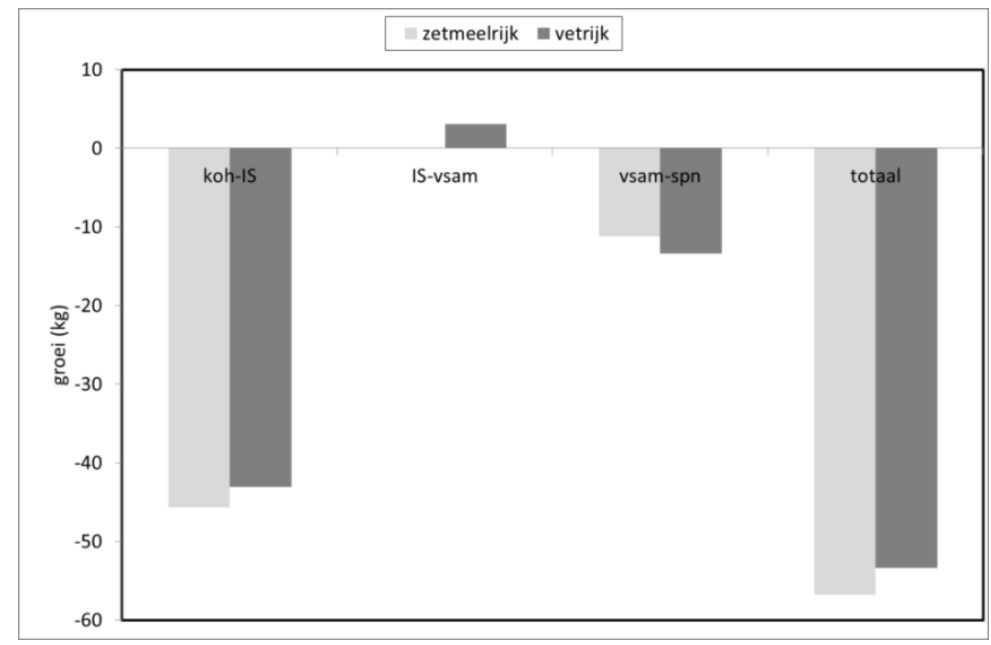

Figuur 1 Gewichtsafname/toename van de zeugen tijdens de 6-weekse lactatie; tot start voerbehandeling op dag 34 na werpen kregen alle zeugen hetzelfde lactovoer; daarna kregen de zeugen tot spenen op dag 42 een zetmeelrijk of vetrijk lactovoer verstrekt. koh-IS = inzet kraamstal tot start IS, IS-vsam = start IS tot start voerbehandeling, vsam-spn = start voerbehandeling tot spenen, totaal = inzet kraamstal tot spenen.

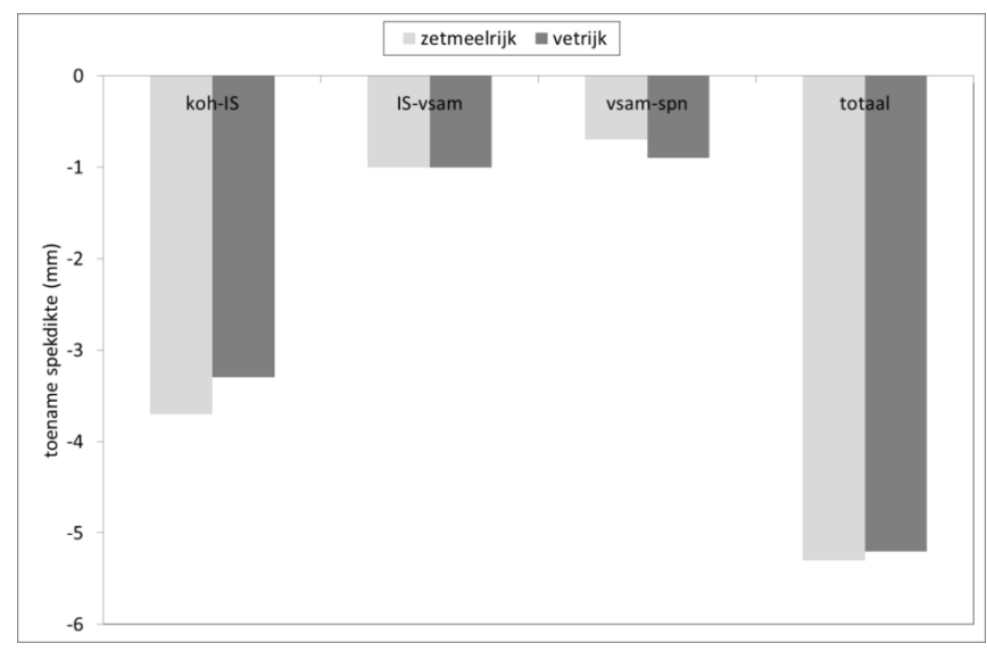

Figuur 2 Spekdikte afname van de zeugen tijdens de 6-weekse lactatie; tot start voerbehandeling op dag 34 na werpen kregen alle zeugen hetzelfde lactovoer; daarna kregen de zeugen tot spenen op dag 42 een zetmeelrijk of vetrijk lactovoer verstrekt. koh-IS = inzet kraamstal tot start IS, IS-vsam = start IS tot start voerbehandeling, vsam-spn = start voerbehandeling tot spenen, totaal = inzet kraamstal tot spenen. 
Er was een effect van pariteit op de gewichts- en spekdikte ontwikkeling van de zeugen (bijlage 3). Op alle meetmomenten waren de oudere zeugen (pariteit 5-7) zwaarder en hadden dikker spek dan de jonge zeugen (pariteit 2). Het gewicht van de pariteit $3+4$ zeugen zat hier tussen in. De spekdikte van de pariteit 3+4 zeugen was vergelijkbaar met die van de pariteit 2 zeugen. De gewichts- en spekdikte afname van start voerniveau tot spenen was vergelijkbaar bij alle pariteiten (bijlage 4).

\subsubsection{Productieresultaten}

De productieresultaten van de zeugen zijn weergegeven in tabel 4 . De productieresultaten per pariteit en per behandeling per pariteit (pariteit 2 , pariteit $3+4$ en pariteit $5+6+7$ ) zijn weergegeven in bijlage 5. Voor geen enkel kenmerk was er sprake van een significante interactie tussen voerbehandeling en pariteit.

Tabel 4

Productieresultaten tijdens de 6-weekse lactatie; tot start voerbehandeling op dag 34 na werpen kregen alle zeugen hetzelfde lactovoer; daarna kregen de zeugen tot spenen op dag 42 een zetmeelrijk of vetrijk lactovoer verstrekt.

\begin{tabular}{|c|c|c|c|c|}
\hline & \multicolumn{2}{|c|}{ Voersamenstelling } & \multirow[t]{2}{*}{$S_{S E M^{1}}$} & \multirow[t]{2}{*}{ P-waarde } \\
\hline & zetmeelrijk & vetrijk & & \\
\hline Aantal worpen & 52 & 51 & & \\
\hline Totaal geboren biggen & 17,2 & 16,7 & & 0,46 \\
\hline Levend geboren biggen & 15,8 & 15,6 & & 0,73 \\
\hline Doodgeboren biggen & 1,4 & 1,1 & & 0,37 \\
\hline Geboortegewicht levend geboren biggen $(\mathrm{kg})$ & 1,35 & 1,34 & 0,027 & 0,87 \\
\hline Spreiding in geboortegewicht $(\mathrm{kg})$ & 0,278 & 0,292 & 0,011 & 0,33 \\
\hline Beginaantal biggen ${ }^{2}$ & 14,2 & 14,7 & & 0,19 \\
\hline Geboortegewicht beginaantal $(\mathrm{kg})^{2}$ & 1,40 & 1,42 & 0,028 & 0,65 \\
\hline Aantal gespeende biggen & 12,3 & 12,4 & & 0,93 \\
\hline Speenleeftijd & 41,7 & 41,5 & 0,25 & 0,45 \\
\hline Speengewicht (kg) & 11,5 & 11,4 & 0,18 & 0,55 \\
\hline Groei $(g / d)$ & 242 & 240 & 3,9 & 0,67 \\
\hline Voeropname per big $(\mathrm{kg})$ & 1,17 & 1,09 & 0,10 & 0,59 \\
\hline
\end{tabular}

${ }^{1} \mathrm{SEM}=$ gepoolde standaard error van het gemiddelde; ${ }^{2}$ Beginaantal = levend geboren + bijgelegd - weggelegd

Uit tabel 4 blijkt dat het aantal levend en doodgeboren biggen en het geboortegewicht van de levend geboren biggen vergelijkbaar waren bij de zeugen die vanaf 34 dagen na werpen een zetmeelrijk of een vetrijk voer kregen. Ook het aantal gespeende biggen, het speengewicht van de biggen, de groei van de biggen tijdens de zoogperiode en de voeropname van de biggen waren vergelijkbaar bij de zeugen op het zetmeelrijke of vetrijke voer.

Het speengewicht van de biggen en de groei van de biggen tijdens de zoogperiode verschilden niet duidelijk tussen de pariteit 2 , pariteit $3+4$ en pariteit $5+6+7$ zeugen (bijlage 5 ). Het aantal gespeende biggen was hoger bij de pariteit $3+4$ zeugen dan bij de pariteit $5+6+7$ zeugen.

De resultaten van de zuigende biggen van geboorte tot start IS op dag 27, van start IS tot start voerniveau op dag 34 en van start voerniveau tot spenen zijn weergegeven in tabel 5 . De productieresultaten per pariteit en per behandeling per pariteit (pariteit 2, pariteit $3+4$ en pariteit $5+6+7$ ) zijn weergegeven in bijlage 6 .Voor geen enkel kenmerk was er sprake van een significante interactie tussen voerbehandeling en pariteit.

Uit tabel 5 blijkt dat er tot start voerbehandeling op dag 34 geen verschil was in groei en voeropname van de zuigende biggen. Vanaf start voerbehandeling tot spenen was er eveneens geen significant verschil in groei en voeropname tussen de twee groepen biggen. Ook het speengewicht verschilde niet tussen de twee groepen biggen.

De biggen van pariteit 2 zeugen groeiden van start voerbehandeling tot spenen duidelijk langzamer dan biggen van pariteit $3+4$ en pariteit $5+6+7$ zeugen ( 232 vs 278 vs $291 \mathrm{~g} / \mathrm{d}$; p = 0,03). 


\section{Tabel 5}

Resultaten van de zuigende biggen tijdens de 6-weekse lactatie; tot start voerbehandeling op dag 34 na werpen kregen alle zeugen hetzelfde lactovoer; daarna kregen de zeugen tot spenen op dag 42 een zetmeelrijk of vetrijk lactovoer verstrekt.

\begin{tabular}{|c|c|c|c|c|}
\hline & \multicolumn{2}{|c|}{ Voersamenstelling } & \multirow[t]{2}{*}{$S E M^{1}$} & \multirow[t]{2}{*}{ P-waarde } \\
\hline & zetmeelrijk & vetrijk & & \\
\hline \multicolumn{5}{|l|}{ Geboorte tot start IS op dag 27} \\
\hline Beginaantal biggen & 14,2 & 14,7 & & 0,19 \\
\hline Geboortegewicht beginaantal (kg) & 1,40 & 1,42 & 0,028 & 0,65 \\
\hline Spreiding in geboortegewicht beginaantal $(\mathrm{kg})$ & 0,217 & 0,222 & 0,009 & 0,66 \\
\hline Groei $(g / d)$ & 254 & 255 & 3,5 & 0,92 \\
\hline Voeropname per big (kg) & 0,33 & 0,33 & 0,021 & 0,99 \\
\hline \multicolumn{5}{|l|}{ Start IS tot start voerbehandeling op dag 34} \\
\hline Aantal biggen bij start IS & 12,4 & 12,4 & & 0,91 \\
\hline Gewicht bij start IS (kg) & 8,2 & 8,1 & 0,12 & 0,76 \\
\hline Spreiding in gewicht bij start IS (kg) & 1,21 & 1,27 & 0,05 & 0,36 \\
\hline Groei $(g / d)$ & 164 & 164 & 6,8 & 0,97 \\
\hline Voeropname per big (kg) & 0,25 & 0,28 & 0,027 & 0,52 \\
\hline \multicolumn{5}{|l|}{ Start voerbehandeling tot spenen op dag 42} \\
\hline Aantal biggen bij start voerniveau & 12,3 & 12,4 & & 0,82 \\
\hline Gewicht bij start voerniveau (kg) & 9,3 & 9,3 & 0,14 & 0,79 \\
\hline Spreiding in gewicht bij start voerniveau $(\mathrm{kg})$ & 1,28 & 1,37 & 0,05 & 0,27 \\
\hline Aantal gespeende biggen & 12,3 & 12,4 & & 0,93 \\
\hline Gewicht bij spenen (kg) & 11,5 & 11,4 & 0,18 & 0,55 \\
\hline Spreiding in gewicht bij spenen (kg) & 1,63 & 1,69 & 0,07 & 0,53 \\
\hline Groei $(g / d)$ & 273 & 260 & 11,3 & 0,42 \\
\hline Voeropname per big (kg) & 0,58 & 0,47 & 0,067 & 0,23 \\
\hline
\end{tabular}

${ }^{1}$ SEM $=$ gepoolde standaard error van het gemiddelde

Het aantal uitgevallen zuigende biggen per toom is weergegeven in tabel 6 .

\section{Tabel 6}

Aantal uitgevallen zuigende biggen per toom tijdens de 6-weekse lactatie; tot start voerbehandeling op dag 34 na werpen kregen alle zeugen hetzelfde lactovoer; daarna kregen de zeugen tot spenen op dag 42 een zetmeelrijk of vetrijk lactovoer verstrekt.

\begin{tabular}{lccc}
\hline & Voersamenstelling & P-waarde \\
\hline & zetmeelrijk & vetrijk & \\
\hline Beginaantal biggen & 14,2 & 14,7 & 0,19 \\
Aantal uitgevallen biggen per toom: & & & \\
- van geboorte tot start IS op dag 27 & 1,80 & 2,34 & 0,24 \\
- van start IS tot start voerbehandeling op dag 34 & 0,03 & 0,00 & 0,35 \\
- van start voerbehandeling tot spenen op dag 42 & 0,00 & 0,03 & 0,24 \\
- van geboorte tot spenen & 1,82 & 2,37 & 0,23 \\
\hline
\end{tabular}

Uit tabel 6 blijkt dat er tot start voerbehandeling op dag 34 geen verschil was in het aantal uitgevallen biggen per toom. Van start voerbehandeling tot spenen op dag 42 was er eveneens geen verschil in het aantal uitgevallen biggen per toom tussen de twee groepen biggen. 


\subsubsection{Reproductieresultaten}

Van de 103 zeugen die ingezet zijn in het onderzoek zijn er 79 (is 76,7\%) binnen 6 dagen na start van de IS berig geworden. Dit percentage was vergelijkbaar bij de zeugen die daarna het zetmeelrijke of vetrijke lactovoer kregen (76,9 versus 76,4\%). De follikelgrootte op dag 0 (woensdag: dag start IS) ( 3,8 versus $3,8 \mathrm{~mm}$ ) en dag 5 (maandag: 5 dagen na start IS) $(6,6$ versus $6,7 \mathrm{~mm}$ ) en de follikelgroei van dag 0 tot 5 ( 2,9 versus $2,9 \mathrm{~mm}$ ) waren eveneens vergelijkbaar bij de zeugen die na inseminatie tijdens de lactatie het zetmeelrijke of het vetrijke lactovoer kregen.

Van de in totaal 79 zeugen die binnen 6 dagen na start van de IS zijn geïnsemineerd, waren er 65 drachtig vier weken na inseminatie (is $82,3 \%$ ). Van de 14 zeugen die niet drachtig waren vier weken na inseminatie zijn er 6 binnen 16 dagen na inseminatie (is binnen 6 dagen na spenen) teruggekomen, 5 op 3 weken na inseminatie en 3 op 4 weken na inseminatie. In tabel 7 zijn de follikelgrootte op dag 0 (dag start IS) en dag 5 ( 5 dagen na start IS) en de grootte van de corpora lutea $(\mathrm{CL})$ op de dag van spenen (is dag 15 ) weergegeven van de 65 zeugen die drachtig waren vier weken na inseminatie en van de 14 zeugen die niet drachtig waren.

\section{Tabel 7}

Follikelgrootte ( $\mathrm{mm}$ ) op dag 0 (dag start IS) en dag 5 ( 5 dagen na start IS) en grootte van de corpora lutea $(\mathrm{mm})$ op de dag van spenen van de zeugen die wel en niet drachtig waren van de inseminatie tijdens IS.

\begin{tabular}{lccc}
\hline & Geinsemineerd tijdens IS & P-waarde \\
\hline & Drachtig & Niet drachtig & \\
\hline Aantal zeugen & 65 & 14 & 0,26 \\
Follikelgrootte op dag 0 & 3,8 & 4,0 & 0,41 \\
Follikelgrootte op dag 5 & 6,9 & 6,8 & 0,30 \\
Corpora lutea (CL) op dag 15 & & 9 & \\
$-\quad$ aantal zeugen & 65 & 8,5 & \\
- CL grootte & 8,7 & 5 & \\
Follikels op dag 15 & & 4,3 & \\
$-\quad$ aantal zeugen & 0 &
\end{tabular}

Uit tabel 7 blijkt dat de follikelgrootte op dag 0 en dag 5 na start IS vergelijkbaar was bij de zeugen die wel en niet drachtig waren vier weken na inseminatie. Ook de grootte van de CLs op de dag van spenen was vergelijkbaar bij de zeugen die wel en niet drachtig waren vier weken na inseminatie. Van de 14 zeugen die niet drachtig waren, hadden er vijf niet geövuleerd. Deze vijf zeugen zijn allemaal teruggekomen binnen 16 dagen na inseminatie (is binnen 6 dagen na spenen). De follikelgrootte van deze vijf zeugen op de dag van spenen was $4,3 \mathrm{~mm}$.

In tabel 8 is het percentage zeugen weergegeven dat op 28 dagen na inseminatie drachtig was. Het is weergegeven per voersamenstelling tijdens de lactatie (zetmeelrijk versus vetrijk) en per voerniveau tijdens de dracht (hoog versus standaard voerniveau). 


\section{Tabel 8}

Percentage drachtige zeugen 4 weken na inseminatie; tot start voerbehandeling op dag 34 na werpen kregen alle zeugen hetzelfde lactovoer; daarna kregen de zeugen tot spenen op dag 42 een zetmeelrijk of vetrijk lactovoer verstrekt. Na spenen werden de zeugen tot 34 dagen dracht volgens een hoog $(3,5 \mathrm{~kg} / \mathrm{d})$ of standaard $(2,8 \mathrm{~kg} / \mathrm{d})$ voerschema gevoerd.

\begin{tabular}{|c|c|c|c|c|c|c|}
\hline & \multicolumn{2}{|c|}{$\begin{array}{c}\text { Voersamenstelling } \\
\text { lactatie }\end{array}$} & \multirow[t]{2}{*}{ P-waarde } & \multicolumn{2}{|c|}{ Voerniveau dracht } & \multirow[t]{2}{*}{ P-waarde } \\
\hline & Zetmeelrijk & vetrijk & & Hoog & Standaard & \\
\hline Percentage drachtig $^{1}$ & 80,0 & 84,6 & 0,59 & 92,5 & 71,8 & 0,02 \\
\hline Percentage drachtig ${ }^{2}$ & 86,5 & 89,2 & 0,72 & 92,5 & 82,4 & 0,18 \\
\hline
\end{tabular}

${ }^{1}$ uitgedrukt als \% van het aantal berige zeugen; alle zeugen die op 4 weken drachtig waren, hebben ook afgebigd van deze inseminatie. ${ }^{2}$ uitgedrukt als \% van het aantal zeugen dat geövuleerd heeft.

Uit tabel 8 blijkt dat het \% drachtige zeugen vier weken na inseminatie niet significant verschilde tussen de zeugen die het zetmeelrijke of vetrijke lactovoer kregen na inseminatie tijdens de lactatie. Bij de zeugen die op het hoge voerniveau werden gevoerd tot 34 dagen dracht was het \% drachtige zeugen vier weken na inseminatie (uitgedrukt als \% van het aantal berige zeugen) significant hoger dan bij de zeugen die op het standaard voerniveau werden gevoerd. De vijf zeugen die niet geövuleerd hebben, waren per toeval allemaal ingedeeld bij het standaard voerniveau. Het percentage drachtige zeugen (uitgedrukt als \% van het aantal zeugen dat geövuleerd heeft) is numeriek, maar niet significant, lager bij de zeugen op het standaard voerniveau. Het lagere percentage drachtige zeugen (uitgedrukt als \% van het aantal zeugen dat geövuleerd heeft) werd m.n. gevonden bij de zeugen die tijdens de laatste 8 dagen van de voorgaande lactatie het zetmeelrijke lactovoer kregen ( 95,0 en $76,5 \%$ op respectievelijk het hoge en standaard voerniveau) en niet bij de zeugen die het vetrijke voer kregen ( 90,0 en $88,0 \%$ op respectievelijk het hoge en standaard voerniveau) ( $p$-waarde interactie $=0,33$ ).

\subsubsection{Melkmonsters en progesteron}

Op de dag van spenen op dag 42 na werpen zijn melkmonsters genomen bij 96 van de 103 zeugen. $\mathrm{Bij} 7$ zeugen in ronde 2 zijn geen melkmonsters genomen. In de melkmonsters zijn de gehalten aan droge stof, vet, eiwit, lactose en progesteron bepaald. In tabel 9 is de melksamenstelling weergegeven van alle 96 zeugen en van de 63 drachtige zeugen. 


\section{Tabel 9}

Melksamenstelling van de zeugen bij spenen op dag 42 na werpen; tot start voerbehandeling op dag 34 na werpen kregen alle zeugen hetzelfde lactovoer; daarna kregen de zeugen tot spenen op dag 42 een zetmeelrijk of vetrijk lactovoer verstrekt.

\begin{tabular}{|c|c|c|c|c|}
\hline & \multicolumn{2}{|c|}{ Voersamenstelling } & \multirow[t]{2}{*}{ SEM ${ }^{1}$} & \multirow[t]{2}{*}{ P-waarde } \\
\hline & zetmeelrijk & vetrijk & & \\
\hline \multicolumn{5}{|l|}{ Alle zeugen: } \\
\hline - Aantal monsters & 47 & 49 & & \\
\hline - Droge stof $(\mathrm{g} / \mathrm{kg})^{2}$ & 171 & 177 & 2,4 & 0,11 \\
\hline - Ruw eiwit $(\mathrm{g} / \mathrm{kg})^{3}$ & 61 & 59 & 1,4 & 0,31 \\
\hline - Vet $(\mathrm{g} / \mathrm{kg})$ & 57 & 60 & 2,0 & 0,26 \\
\hline - Lactose $(\mathrm{g} / \mathrm{kg})^{4}$ & 49,9 & 49,2 & 0,53 & 0,32 \\
\hline - Lactose monohydraat $(\mathrm{g} / \mathrm{kg})^{4}$ & 52,5 & 51,8 & 0,56 & 0,32 \\
\hline - Progesteron (ng/ml) & 13,7 & 12,6 & 0,84 & 0,36 \\
\hline \multicolumn{5}{|l|}{ Drachtige zeugen: } \\
\hline - Aantal monsters & 31 & 32 & & \\
\hline - Droge stof $(\mathrm{g} / \mathrm{kg})^{2}$ & 169 & 175 & 3,1 & 0,19 \\
\hline - Ruw eiwit $(\mathrm{g} / \mathrm{kg})^{3}$ & 61 & 59 & 2,0 & 0,36 \\
\hline - Vet $(\mathrm{g} / \mathrm{kg})$ & 56 & 59 & 2,3 & 0,40 \\
\hline - Lactose $(\mathrm{g} / \mathrm{kg})^{5}$ & 49,6 & 48,9 & 0,70 & 0,46 \\
\hline - Lactose monohydraat $(\mathrm{g} / \mathrm{kg})^{5}$ & 52,2 & 51,4 & 0,73 & 0,46 \\
\hline - Progesteron $(\mathrm{ng} / \mathrm{ml})$ & 16,3 & 15,1 & 0,44 & 0,07 \\
\hline
\end{tabular}

${ }^{1} \mathrm{SEM}=$ gepoolde standaard error van het gemiddelde); ${ }^{2}$ In drie monsters ( $3 \times$ zetmeelrijk voer) is het droge stof gehalte niet bepaald omdat de hoeveelheid monster te klein was; ${ }^{3}$ In één monster (zetmeelrijk voer) is het ruw eiwit gehalte niet bepaald omdat de hoeveelheid monster te klein was; ${ }^{4}$ In 9 melkmonsters ( $7 \times$ zetmeelrijk voer en $2 \times$ vetrijk voer) is het lactose gehalte niet bepaald omdat de hoeveelheid monster te klein was; ${ }^{5}$ In 6 melkmonsters ( $6 \times$ zetmeelrijk voer) is het lactose gehalte niet bepaald.

Uit tabel 9 blijkt dat er geen significante verschillen zijn in de gehalten aan droge stof, ruw eiwit, vet en lactose in de melk tussen de zeugen die het zetmeelrijke of vetrijke voer kregen tijdens de laatste 8 dagen van de 6-weekse lactatie.

In de melkmonsters van de drachtige zeugen tendeert het progesterongehalte naar hoger in de zeugen die het zetmeelrijke voer kregen.

In 14 gepoolde melkmonsters (per ronde per voersamenstelling tijdens de lactatie zijn de melkmonsters gepoold) is de vetzuursamenstelling bepaald. De vetzuursamenstelling is weergegeven in tabel 10. 
Tabel 10

Vetzuursamenstelling (\% van vet) in melkmonsters van zeugen bij spenen op dag 42 na werpen; tot start voerbehandeling op dag 34 na werpen kregen alle zeugen hetzelfde lactovoer; daarna kregen de zeugen tot spenen op dag 42 een zetmeelrijk of vetrijk lactovoer verstrekt.

\begin{tabular}{lccc}
\hline & Voersamenstelling & P-waarde \\
\hline & zetmeel rijk & vetrijk & \\
\hline Aantal monsters & 7 & 7 & \\
Verzadigde vetzuren & 42,3 & 39,3 & 0,005 \\
Enkelvoudig onverzadigde vetzuren & 41,4 & 41,0 & 0,68 \\
Meervoudig onverzadigde vetzuren & 15,9 & 19,3 & 0,002 \\
Transvetzuren & 0,39 & 0,34 & 0,36 \\
Caprinezuur (C10:0) & 0,23 & 0,19 & 0,08 \\
Laurinezuur (C12:0) & 0,84 & 0,79 & 0,46 \\
Myristinezuur (C14:0) & 3,83 & 3,51 & 0,02 \\
Myristine oleic zuur (C14:1n5) & 0,33 & 0,23 & 0,02 \\
Pentadinezuur (C15:0) & 0,13 & 0,10 & 0,17 \\
Palmitinezuur (C16:0) & 32,4 & 30,0 & 0,01 \\
Palmitoleïne zuur (C16:1n7) & 10,2 & 7,67 & 0,009 \\
Heptadecaanzuur (C17:0) & 0,23 & 0,20 & 0,17 \\
C17:1 & 0,33 & 0,23 & 0,02 \\
Stearinezuur (C18:0) & 3,86 & 3,80 & 0,83 \\
Oliezuur (C18:1n9) & 28,2 & 30,4 & 0,16 \\
C18:1n overig & 1,90 & 1,93 & 0,84 \\
Linolzuur (C18:2n6) & 13,6 & 16,6 & 0,004 \\
Linoleenzuur (18:3n3) & 1,06 & 1,34 & 0,02 \\
Eicoseenzuur (C20:1n9) & 0,33 & 0,34 & 0,77 \\
Eicosadieen zuur (C20:2n6) & 0,27 & 0,29 & 0,60 \\
Arachidonzuur (C20:4n6) & 0,36 & 0,40 & 0,20 \\
\hline
\end{tabular}

Uit tabel 10 blijkt dat de vetzuursamenstelling verschilt tussen de zeugen die het zetmeelrijke of vetrijke voer kregen tijdens de laatste 8 dagen van de 6 -weekse lactatie. In de melk van zeugen die het vetrijke voer kregen was het percentage verzadigde vetzuren, myristinezuur, myristine oleic zuur, pamitinezuur, palmitoleïne zuur en C17:1 in het vet significant lager en het percentage meervoudig onverzadigde vetzuren, linolzuur en linoleenzuur significant hoger dan in de melk van zeugen die het zetmeelrijke voer kregen.

\subsubsection{Diarreescores biggen}

Vanaf de dag voor start IS tot spenen zijn tweemaal per week (in totaal zes keer) diarreescores (mestconsistentie en kleur) bij de biggen uitgevoerd. De eerste meting is voor de start IS uitgevoerd, de tweede en derde meting tijdens IS (de dag na start IS en de dag voor start voerbehandeling) en de vierde $\mathrm{t} / \mathrm{m}$ zesde meting tijdens de voerbehandeling (dag na start voerbehandeling, twee dagen voor spenen en de dag van spenen). In tabel 11 is het percentage biggen met diarree weergegeven op de dag voor start IS, tijdens IS en tijdens de voerbehandeling .

Uit tabel 11 blijkt dat op de dag voor start IS en tijdens IS er geen verschillen waren in mestconsistentie tussen de twee groepen biggen. Tijdens de voerbehandeling kwam er bij de biggen van zeugen op het vetrijke voer meer diarree (pasteuze en waterdunne mest) voor dan bij de biggen van zeugen op het zetmeelrijke voer. 


\section{Tabel 11}

Mestconsistentie bij biggen op de dag voor start IS, tijdens IS en tijdens de voerbehandeling (in percentage van het aantal biggen); tot start voerbehandeling op dag 34 na werpen kregen alle zeugen hetzelfde lactovoer; daarna kregen de zeugen tot spenen op dag 42 een zetmeelrijk of vetrijk lactovoer verstrekt.

\begin{tabular}{lccc}
\hline & Voersamenstelling & P-waarde \\
\hline & & & \\
\hline Dag voor start IS: & 92,8 & 94,9 & 0,53 \\
- normale mest & 6,9 & 5,1 & \\
- pasteuze mest & 0,3 & 0,0 & \\
- waterdunne mest & & & \\
& & & 0,41 \\
Tijdens IS: & 90,9 & 88,5 & \\
- normale mest & 6,4 & 7,5 & \\
- pasteuze mest & 2,7 & 4,0 & \\
- waterdunne mest & & & \\
& & & \\
Tijdens de voerbehandeling: & 77,2 & 69,5 & \\
- normale mest & 13,7 & 18,8 & \\
- pasteuze mest & 9,1 & 11,7 & \\
- waterdunne mest & & & \\
\hline
\end{tabular}

In tabel 12 is het percentage biggen met gelige, grijze en zwarte/bruine mest weergegeven op de dag voor start IS, tijdens IS en tijdens de voerbehandeling.

\section{Tabel 12}

Kleur van de mest bij biggen op de dag voor start IS, tijdens IS en tijdens de voerbehandeling (in percentage van het aantal biggen); tot start voerbehandeling op dag 34 na werpen kregen alle zeugen hetzelfde lactovoer; daarna kregen de zeugen tot spenen op dag 42 een zetmeelrijk of vetrijk lactovoer verstrekt.

\begin{tabular}{lccc}
\hline & Voersamenstelling & P-waarde \\
\hline & & vetrijk & \\
\hline Dag voor start IS: & 8,4 & 5,2 & 0,45 \\
- gelige mest & 3,3 & 3,1 & \\
- grijze mest & 88,3 & 91,7 & \\
- zwarte/bruine mest & & & \\
& & & 0,92 \\
Tijdens IS: & 6,3 & 7,0 & \\
- gelige mest & 6,1 & 5,7 & \\
- grijze mest & 87,6 & 87,3 & \\
- zwarte/bruine mest & & & 0,04 \\
& & & \\
Tijdens de voerbehandeling: & 8,1 & 13,2 & \\
- gelige mest & 14,7 & 16,5 & \\
- grijze mest & 77,2 & 70,3 & \\
- zwarte/bruine mest & & & \\
\hline
\end{tabular}

Uit tabel 12 blijkt dat op de dag voor start IS en tijdens IS er geen verschillen waren in kleur van de mest tussen de twee groepen biggen. Tijdens de voerbehandeling kwam er meer gelige mest voor bij de biggen van zeugen op het vetrijke voer dan bij de biggen van zeugen op het zetmeelrijke voer. 


\subsection{Volgende worp}

\subsubsection{Voeropname, gewicht en spekdikte van de zeugen}

Van de 103 zeugen die in de vorige worp zijn ingezet in het onderzoek, zijn er 79 berig geworden en hebben er 65 afgebigd van $1^{\text {ste }}$ inseminatie. De voeropname in de drachtstal en de gewichts- en spekdikte ontwikkeling van deze 65 zeugen in de volgende worp is weergegeven in tabel 13 . Het is weergegeven per voersoort tijdens de lactatie (zetmeelrijk versus vetrijk) en per voerniveau tijdens de dracht (hoog versus standaard voerniveau). De gewichten en spekdikten per pariteit en per voerbehandeling per pariteit (pariteit 3 , pariteit $4+5$ en pariteit $6+7+8$ ) zijn weergegeven in bijlage 7 . Voor geen enkel kenmerk was er sprake van een significante interactie tussen voerbehandeling en pariteit.

\section{Tabel 13}

Voeropname in de drachtstal en gewichten en spekdikten van de zeugen in de volgende worp; in de voorgaande lactatie zijn de zeugen geïnsemineerd tijdens een 6-weekse lactatie en kregen ze tijdens de laatste 8 dagen van de lactatie een zetmeelrijk of vetrijk voer verstrekt; na spenen werden de zeugen tot 34 dagen dracht volgens een hoog $(3,5 \mathrm{~kg} / \mathrm{d})$ of standaard $(2,8 \mathrm{~kg} / \mathrm{d})$ voerschema gevoerd.

\begin{tabular}{|c|c|c|c|c|c|c|c|c|}
\hline & \multicolumn{2}{|c|}{$\begin{array}{c}\text { Voersamenstelling } \\
\text { lactatie }\end{array}$} & $S E M^{1}$ & \multirow[t]{2}{*}{ Waarde } & \multicolumn{2}{|c|}{$\begin{array}{l}\text { Voerniveau } \\
\text { dracht }\end{array}$} & \multirow[t]{2}{*}{$S E M^{1}$} & \multirow[t]{2}{*}{ Waarde } \\
\hline & $\begin{array}{c}\text { zetmeel } \\
\text { rijk }\end{array}$ & vetrijk & & & hoog & standaard & & \\
\hline Aantal zeugen & 32 & 33 & & & 37 & 28 & & \\
\hline \multicolumn{9}{|c|}{ Voeropname drachtstal $(\mathrm{kg} / \mathrm{d})$ : } \\
\hline - spenen tot dag 34 & 3,16 & 3,14 & 0,015 & 0,57 & 3,49 & 2,80 & 0,016 & $<0,001$ \\
\hline $\begin{array}{l}\text { - dag } 35 \text { tot inzet } \\
\text { kraamstal }\end{array}$ & 2,97 & 2,97 & 0,004 & 0,80 & 2,98 & 2,97 & 0,004 & 0,33 \\
\hline \multicolumn{9}{|l|}{ Gewicht (kg): } \\
\hline $\begin{array}{l}\text { - inzet kraamstal } \\
\text { vorige worp }\end{array}$ & 268 & 264 & 3,4 & 0,32 & 267 & 266 & 3,5 & 0,82 \\
\hline - spenen vorige worp & 212 & 212 & 3,2 & 0,95 & 211 & 213 & 3,4 & 0,61 \\
\hline - inzet kraamstal & 275 & 277 & 3,5 & 0,70 & 279 & 272 & 3,7 & 0,19 \\
\hline - spenen op dag 27 & 235 & 234 & 3,3 & 0,87 & 233 & 235 & 3,5 & 0,57 \\
\hline \multicolumn{9}{|l|}{ Spekdikte $(\mathrm{mm})$ : } \\
\hline $\begin{array}{l}\text { - inzet kraamstal } \\
\text { vorige worp }\end{array}$ & 16,5 & 15,5 & 0,47 & 0,12 & 15,8 & 16,2 & 0,50 & 0,61 \\
\hline - spenen vorige worp & 11,0 & 10,4 & 0,40 & 0,29 & 10,6 & 10,8 & 0,41 & 0,75 \\
\hline - dag 28 dracht & 11,7 & 11,4 & 0,38 & 0,58 & 11,7 & 11,3 & 0,40 & 0,52 \\
\hline - dag 77 dracht & 13,7 & 13,2 & 0,40 & 0,42 & 13,7 & 13,2 & 0,42 & 0,46 \\
\hline - inzet kraamstal & 14,9 & 15,1 & 0,43 & 0,78 & 15,1 & 14,8 & 0,45 & 0,64 \\
\hline - spenen op dag $27^{2}$ & 12,1 & 11,9 & 0,38 & 0,72 & 11,9 & 12,0 & 0,40 & 0,85 \\
\hline
\end{tabular}

${ }^{1} \mathrm{SEM}=$ gepoolde standaard error van het gemiddelde; ${ }^{2} \mathrm{Er}$ is een significante interactie tussen voersamenstelling lactatie en voerniveau dracht. Bij het zetmeelrijke voer was de spekdikte bij het hoge en standaard voerniveau respectievelijk 11,5 en $12,9 \mathrm{~mm}$, bij het vetrijke voer was dit respectievelijk 12,4 en $11,4 \mathrm{~mm}$.

Uit tabel 13 blijkt dat er in de drachtstal geen verschil in voeropname was tussen de zeugen die tijdens de laatste 8 dagen van de voorgaande lactatie een zetmeelrijk of vetrijk lactovoer kregen. De zeugen die tot 34 dagen dracht op een hoog voerniveau gevoerd werden, hebben in deze periode duidelijk meer voer opgenomen dan de zeugen die op het standaard voerniveau gevoerd werden. 
Bij het spenen van de vorige worp, bij inzet in de kraamstal in de volgende worp en bij spenen van de volgende worp waren er geen duidelijke verschillen in gewicht en spekdikte tussen de zeugen die in de laatste 8 dagen van de voorgaande lactatie een zetmeelrijk of een vetrijk lactovoer kregen. Ook was er geen duidelijk verschil in gewichtstoename van spenen van de vorige worp tot inzet in de kraamstal $(62,3$ en $64,5 \mathrm{~kg} ; \mathrm{p}=0,53)$. Wel was er een tendens tot meer spekdikte toename bij de zeugen op het vetrijke voer $(3,9$ en $4,7 \mathrm{~mm} ; \mathrm{p}=0,08)$.

$\mathrm{Bij}$ het spenen van de vorige worp was er geen verschil in gewicht en spekdikte tussen de zeugen die daarna tot 34 dagen dracht op een hoog of standaard voerniveau werden gevoerd. Ook bij inzet in de kraamstal en bij spenen van de volgende worp waren er geen duidelijke verschillen in gewicht en spekdikte tussen de zeugen die op een hoog of standaard voerniveau werden gevoerd tot 34 dagen dracht. De zeugen op het hoge voerniveau zijn van spenen tot inzet in de kraamstal in de volgende worp duidelijk meer in gewicht toegenomen dan de zeugen op het standaard voerniveau $(67,8$ versus $59,0 \mathrm{~kg} ; \mathrm{p}=0,01)$. Er was geen duidelijk verschil in spekdikte toename tussen de zeugen op het hoge of standaard voerniveau $(4,5$ versus $4,1 \mathrm{~mm} ; \mathrm{p}=0,29)$.

Er was geen effect van pariteit op de voeropname in de drachtstal. Wel was er een effect van pariteit op de gewichts- en spekdikte ontwikkeling van de zeugen. Op alle meetmomenten waren de oudere zeugen (pariteit 6-8) zwaarder en hadden dikker spek dan de jonge zeugen (pariteit 3). Het gewicht en de spekdikte van de pariteit $4+5$ zeugen zaten hier tussen in (bijlage 7 ).

\subsubsection{Productieresultaten van de zeugen}

De productieresultaten van de 65 zeugen die hebben geworpen van $1^{\text {ste }}$ inseminatie zijn weergegeven in tabel 14. Het is weergegeven per voersoort tijdens de lactatie (zetmeelrijk versus vetrijk) en per voerniveau tijdens de dracht (hoog versus standaard voerniveau) omdat er voor geen enkel kenmerk sprake was van een significante interactie. De productieresultaten per pariteit en per voerbehandeling per pariteit (pariteit 3 , pariteit $4+5$ en pariteit $6+7+8$ ) zijn weergegeven in bijlage 8 .

\section{Tabel 14}

Productieresultaten van de zeugen in de volgende worp; in de voorgaande lactatie zijn de zeugen geïnsemineerd tijdens een 6-weekse lactatie en kregen ze tijdens de laatste 8 dagen van de lactatie een zetmeelrijk of vetrijk voer verstrekt; na spenen werden de zeugen tot 34 dagen dracht volgens een hoog $(3,5 \mathrm{~kg} / \mathrm{d})$ of standaard $(2,8 \mathrm{~kg} / \mathrm{d})$ voerschema gevoerd.

\begin{tabular}{|c|c|c|c|c|c|c|c|c|}
\hline & \multirow{2}{*}{\multicolumn{2}{|c|}{$\begin{array}{c}\text { Voersamenstelling } \\
\text { lactatie }\end{array}$}} & \multirow[t]{3}{*}{$S E M^{1}$} & \multirow{3}{*}{ Waarde } & \multirow{2}{*}{\multicolumn{2}{|c|}{$\begin{array}{l}\text { Voerniveau } \\
\text { dracht }\end{array}$}} & \multirow[t]{3}{*}{$S E M^{1}$} & \multirow{3}{*}{ waarde } \\
\hline & & & & & & & & \\
\hline & $\begin{array}{c}\text { zetmeel } \\
\text { rijk } \\
\end{array}$ & vetrijk & & & hoog & standaard & & \\
\hline Aantal worpen & 32 & 33 & & & 37 & 28 & & \\
\hline Totaal geboren biggen & 15,5 & 15,5 & & 0,96 & 15,9 & 15,0 & & 0,43 \\
\hline Levend geboren biggen & 14,1 & 14,4 & & 0,84 & 14,5 & 14,0 & & 0,69 \\
\hline Doodgeboren biggen & 1,4 & 1,1 & & 0,57 & 1,4 & 1,0 & & 0,36 \\
\hline $\begin{array}{l}\text { Geboortegewicht levend } \\
\text { geboren }(\mathrm{kg})\end{array}$ & 1,35 & 1,27 & 0,036 & 0,12 & 1,33 & 1,29 & 0,037 & 0,43 \\
\hline $\begin{array}{l}\text { Spreiding in } \\
\text { geboortegewicht }(\mathrm{kg})\end{array}$ & 0,282 & 0,300 & 0,016 & 0,39 & 0,287 & 0,295 & 0,016 & 0,72 \\
\hline
\end{tabular}

${ }^{1}$ SEM $=$ gepoolde standaard error van het gemiddelde

Uit tabel 14 blijkt dat het totaal aantal geboren biggen en het aantal levend en dood geboren biggen in de volgende worp niet significant verschilden tussen de zeugen die de laatste 8 dagen van de voorgaande lactatie een zetmeelrijk of een vetrijk voer kregen. Het geboortegewicht van de biggen was numeriek, maar niet significant, hoger bij de zeugen die het zetmeelrijke voer kregen. Er was geen significant effect van voerniveau tijdens de dracht op het totaal aantal geboren biggen en het aantal levend en dood geboren biggen en op het geboortegewicht van de biggen. Tevens was er geen effect van pariteit op het aantal levend geboren biggen en het geboortegewicht van de biggen. 


\subsection{Relaties}

Nagegaan is of er relaties waren tussen:

- Gewicht en spekdikte bij start voerbehandeling en gewichts- en spekdikteverlies tijdens de laatste 8 dagen van de zoogperiode met groei en voeropname van de biggen in deze periode.

- $\quad$ Gewichts- en spekdikteverlies tijdens de hele zoogperiode en tijdens de laatste 8 dagen van de zoogperiode met totaal aantal geboren biggen, aantal levend geboren biggen in de volgende worp en geboortegewicht van de levend geboren biggen.

Bij alle relaties was de $\mathrm{R}^{2}$ erg laag (minder dan $8 \%$ ) en slechts drie relaties waren significant. Er was een negatieve relatie tussen gewichtsafname van de zeugen in de laatste 8 dagen van de 6-weekse zoogperiode en de groei van de biggen in deze periode, een negatieve relatie tussen spekdikte van de zeugen bij start van de voerbehandeling en voeropname van de biggen in de laatste 8 dagen van de 6-weekse zoogperiode en een negatieve relatie tussen spekdikte afname van de zeugen tijdens de 6weekse lactatie en aantal levend geboren biggen in de volgende worp. De significante relaties zijn weergegeven in figuren in bijlage 9. 


\section{Discussie}

Doel van het onderzoek was nagaan wat het effect is van een zetmeelrijk versus een vetrijk lactovoer tijdens de laatste 8 dagen van een 6-weekse lactatie waarin de zeugen ook drachtig zijn op de gewichts- en spekdikte ontwikkeling van de zeugen, de technische resultaten van de biggen en het aantal levend en dood geboren biggen in de volgende worp. Daarnaast is nagegaan wat het effect is van een hoger voerniveau vanaf spenen (ca. 9 dagen na inseminatie) tot 34 dagen dracht op de gewichts- en spekdikte ontwikkeling van de zeugen en de toomgrootte in de volgende worp. Eerste worps zeugen zijn niet ingezet in het onderzoek vanwege de lagere kans op berig worden door IS. De resultaten van het onderzoek kunnen daarom niet vertaald worden naar eerste worps zeugen. Tijdens de laatste 8 dagen van de 6-weekse lactatie, waarin de zeugen ook drachtig waren, kregen de zeugen lactovoer verstrekt en geen drachtvoer omdat de biggen nog zoogden bij de zeug.

\section{Gewichts- en spekdikte ontwikkeling van de zeugen}

Op dag 34 na werpen hadden de zeugen die daarna een zetmeelrijk of vetrijk lactovoer kregen een vergelijkbaar gewicht (223 versus $226 \mathrm{~kg}$ ) en een vergelijkbare spekdikte (11,3 versus 11,3 mm). Tijdens de laatste 8 dagen van de lactatie zijn de zeugen op het zetmeelrijke voer $11 \mathrm{~kg}$ in gewicht afgenomen en verloren 0,6 mm spek. De zeugen op het vetrijke voer zijn $13 \mathrm{~kg}$ in gewicht afgenomen en verloren 0,9 mm spek. Met behulp van de formules van Bergsma et al. (2009) is berekend wat het verlies aan eiwit en vet was tijdens de laatst 8 dagen van de lactatie (tabel 15):

- $\quad$ Eiwit $(\mathrm{kg})=1,90+0,1711 \times$ gewicht $(\mathrm{kg})-0,3113 \times$ spekdikte $(\mathrm{mm})$

- $\quad$ Vet $(\mathrm{kg})=-11,58+0,1027 \times$ gewicht $(\mathrm{kg})+1,904 \times$ spekdikte $(\mathrm{mm})$

\section{Tabel 15}

Hoeveelheid lichaamseiwit $(\mathrm{kg})$ en lichaamsvet $(\mathrm{kg})$ bij lacterende zeugen op dag 34 na werpen en bij spenen op dag 42; tot start voerniveau op dag 34 na werpen kregen alle zeugen hetzelfde lactovoer; daarna kregen de zeugen tot spenen op dag 42 een zetmeelrijk of vetrijk lactovoer verstrekt.

\begin{tabular}{lcc}
\hline & \multicolumn{1}{c}{ Voersamenstelling } \\
\hline Aantal zeugen & zetmeelrijk & vetrijk \\
Eiwit $(\mathrm{kg})$ : & & 51 \\
- bij start voerniveau op dag 34 & & \\
- bij spenen op dag 42 & 36,5 & 37,1 \\
- afname van dag 34 tot dag 42 & 34,8 & 35,1 \\
& 1,7 & 2,0 \\
Vet $(\mathrm{kg})$ : & & 33,1 \\
- bij start voerniveau op dag 34 & 32,8 & 30,1 \\
- bij spenen op dag 42 & 30,6 & 3,0 \\
- afname van dag 34 tot dag 42 & 2,2 & \\
\hline
\end{tabular}

Uit tabel 15 blijkt dat de zeugen op het zetmeelrijke voer tijdens de laatste 8 dagen van de lactatie evenveel eiwit $(4,7$ versus $5,4 \%)$ maar iets minder vet $(6,7$ versus $9,1 \%)$ verliezen dan de zeugen op het vetrijke voer. Soortgelijke effecten op gewichts- en spekdikteverliezen zijn gevonden door Van den Brand et al. (2000). Ook zij vonden geen significant verschil in gewichts- en spekdikte afname tijdens een 3-weekse lactatie tussen zeugen die een zetmeelrijk of een vetrijk lactovoer kregen. Van den Brand et al. (2000a) daarentegen vonden dat zeugen gevoerd op een hoog voerniveau met een zetmeelrijk voer tijdens een 3-weekse lactatie minder gewicht verloren dan zeugen gevoerd op een hoog voerniveau met een vetrijk voer. Bij een laag voerniveau was het gewichtsverlies hoger, maar vergelijkbaar bij de zeugen op het zetmeelrijke en vetrijke voer. In ons onderzoek werden de zeugen in beide groepen op een hoog voerniveau $(8,1 \mathrm{EW} / \mathrm{d})$ gevoerd tijdens de laatste 8 dagen van de 6 weekse lactatie. In beide groepen was de werkelijke EW-opname echter lager (7,03 en 7,35 EW/d op het zetmeelrijke en vetrijke voer). De lagere EW-opname werd grotendeels veroorzaakt door zeven zeugen (vier op het zetmeelrijke voer en drie op het vetrijke voer) met een voeropname van minder 
dan $3,4 \mathrm{~kg} / \mathrm{d}$. Als de zeven zeugen met een voeropname van minder dan $3,4 \mathrm{~kg}$ tijdens de laatste 8 dagen van de lactatie niet meegenomen worden in de resultaten dan zijn het gewichtsverlies ( 9 versus $13 \mathrm{~kg} ; \mathrm{p}=0,11)$, het eiwitverlies $(3,8$ versus $5,4 \%)$ en het vetverlies $(6,4$ versus $8,7 \%)$ iets lager op het zetmeelrijke voer dan op het vetrijke voer. Het lijkt er dus op dat het gewichtsverlies verminderd kan worden door de zeugen op een hoog voerniveau te voeren met een zetmeelrijk voer. Lactose in melk kan alleen uit glucose gesynthetiseerd worden en niet uit vetzuren. Als zeugen een vetrijk voer krijgen gaan ze lichaamseiwit afbreken t.b.v. gluconeogenese (Nelssen et al., 1985). Dit verklaart mogelijk het iets grotere gewichtsverlies op het vetrijke voer.

Ondanks het hoge voerniveau verliezen de zeugen toch nog ca. $10 \mathrm{~kg}$ gewicht en 0,6 mm spek in de laatste 8 dagen van de 6 -weekse lactatie. Dit komt door een hoge melkproductie van de zeugen. Van der Peet-Schwering et al. (2015) gaven aan dat ze verwachtten dat de melkproductie tijdens de IS periode af zou nemen (omdat de zeugen 10 uur per dag van de biggen weg zijn en de biggen vast voer op gaan nemen) en dat de melkproductie daarna op een lager niveau zou blijven. Dit bleek echter niet het geval. Ze berekenden dat de zeugen tijdens de laatste 8 dagen van de 6 -weekse lactatie nog ca. $10 \mathrm{~kg}$ melk per dag produceerden. In het huidige onderzoek hebben de biggen van de zeugen op het zetmeelrijke voer de laatste 8 dagen van de lactatie 0,58 kg speenvoer per big opgenomen. Uitgaande van een voederconversie van 1,3 (Van der Peet-Schwering et al., 2013) zouden de biggen $0,45 \mathrm{~kg}$ in gewicht toegenomen zijn. De biggen zijn echter $2,2 \mathrm{~kg}$ in gewicht toegenomen (van 9,3 kg naar 11,5 kg). Dit betekent dat 1,75 kg gewichtstoename het gevolg is van melkopname bij de zeug. Voor $1 \mathrm{~kg}$ groei is $4,2 \mathrm{~kg}$ melk nodig (Everts et al., 1995). Dit betekent dat de melkproductie van de zeugen ca. $11 \mathrm{~kg}$ per dag was (1,75 kg gewichtstoename x 4,2 x 12,3 biggen / 8 dagen). De biggen van zeugen op het vetrijke voer hebben 0,47 kg speenvoer per big opgenomen tijdens de laatste 8 dagen van de lactatie en zijn 2,1 kg in gewicht toegenomen. Dit betekent dat ook bij de zeugen op het vetrijke voer de melkproductie ca. $11 \mathrm{~kg}$ per dag was. De melkproductie blijft dus op een hoog niveau tijdens de laatste 8 dagen van een 6-weekse lactatie, waarin de biggen continu bij de zeug zijn, en dit verklaart het conditieverlies van de zeugen.

In het onderzoek van Van der Peet-Schwering et al. (2015) bleek dat de zeugen niet in conditie herstelden tijdens de dracht die volgde op de 6-weekse lactatie. Van inzet kraamstal tot inzet kraamstal in de volgende worp verloren de zeugen op het hoge voerniveau $5 \mathrm{~kg}$ gewicht en 3,6 mm spek. Mogelijk kwam dit omdat ze op het standaard voerschema zijn gevoerd in de drachtstal en geen extra voer kregen om te compenseren voor het gewichtsverlies tijdens de 6-weekse lactatie. Daarom is de helft van de zeugen in dit onderzoek op een hoger voerniveau $(3,5 \mathrm{~kg} / \mathrm{d}) \mathrm{gevoerd}$ vanaf spenen (is 9 dagen dracht) tot 34 dagen dracht en de andere helft op het standaard $(2,8 \mathrm{~kg} / \mathrm{d})$ voerniveau. De zeugen op het hoge voerniveau namen $12 \mathrm{~kg}$ toe in gewicht en verloren $0,7 \mathrm{~mm}$ spek van inzet kraamstal in de vorige worp tot inzet kraamstal in de volgende worp. De zeugen op het standaard voerniveau namen $8 \mathrm{~kg}$ toe in gewicht en verloren 1,0 mm spek. Van spenen tot inzet kraamstal namen de zeugen op het hoge voerniveau $68 \mathrm{~kg}$ toe in gewicht en 4,5 $\mathrm{mm}$ in spek en de zeugen op het standaard voerniveau $59 \mathrm{~kg}$ en 4,1 mm spek. Een hoger voerniveau tijdens het begin van de dracht zorgt dus voor een beter herstel van het conditieverlies tijdens de 6-weekse lactatie dan het standaard voerniveau. Ook Dyck and Strain (1983), Topliss (1983) en Hoving et al. (2011) vonden een hogere gewichtstoename van de zeugen bij een hoger voerniveau in de eerste maand van de dracht.

Geconcludeerd kan worden dat het op een hoog voerniveau voeren van een zetmeelrijk voer tijdens de laatste 8 dagen van een 6 -weekse lactatie het conditieverlies tijdens deze periode iets vermindert t.o.v. het voeren van een vetrijk voer. Een hoog voerniveau tijdens het begin van de dracht zorgt voor een beter conditieherstel tijdens de daarop volgende dracht dan het standaard voerniveau.

\section{Berige en drachtige zeugen}

Van de 103 zeugen die ingezet zijn in het onderzoek zijn er 79 (is 76,7\%) binnen 6 dagen na start van de IS berig geworden. Dit is lager dan in het onderzoek van Van der Peet-Schwering et al. (2015) waarin $87,7 \%$ van de zeugen binnen 6 dagen na start van de IS berig werd. De reden hiervoor is niet duidelijk. Beide onderzoeken zijn in hetzelfde seizoen uitgevoerd, er zijn zeugen van dezelfde pariteit en hetzelfde genotype gebruikt en dezelfde wijze van IS en beercontact is toegepast. In onderzoek van Soede et al. (2012) was het percentage zeugen dat ovuleerde duidelijk lager (pariteit 1: 23\%; 
pariteit 2: $85 \%$; pariteit 3: 65\%; pariteit 4: 61\%). In hun onderzoek werden, in tegenstelling tot ons onderzoek, ook eerste worps zeugen ingezet en werd geen beercontact toegepast.

De follikelgrootte op dag 0 (woensdag: dag start IS) en dag 5 (maandag: 5 dagen na start IS) van de zeugen die wel en niet berig zijn geworden is weergegeven in tabel 16. Daarnaast zijn het progesterongehalte in de melk op de dag van spenen en enkele karakteristieken van de zeugen op de dag van start IS weergegeven. Uit tabel 16 blijkt dat de niet berige zeugen significant kleinere follikels hadden op dag 0 en dag 5 na start IS en dat het progesterongehalte in de melk op de dag van spenen duidelijk lager was. Tussen de berige en niet berige zeugen waren er geen significante verschillen in gewicht en spekdikte bij start IS, in gewichts- en spekdikteverlies van inzet kraamstal tot start IS en in toomgrootte en toomgewicht bij start IS.

\section{Tabel 16}

Follikelgrootte op dag 0 en dag 5 na start IS en progesterongehalte in de melk op de dag van spenen van zeugen die wel of niet berig werden binnen 6 dagen na start intermittent suckling;

\begin{tabular}{lccc}
\hline & niet & wel & P-waarde \\
\hline & 24 & 79 & 0,05 \\
\hline Aantal zeugen & 3,6 & 3,8 & $<0,001$ \\
Follikelgrootte dag 0 (mm) & 5,5 & 6,9 & $<0,001$ \\
Follikelgrootte dag 5 (mm) & & & \\
& 19 & 77 & 0,07 \\
Aantal zeugen & 4,9 & 15,01 & 0,93 \\
Progesteron (ng/ml) & & 79 & 0,20 \\
& 24 & 4,2 & 0,25 \\
Aantal zeugen & 4,9 & 222 & 0,63 \\
Pariteit bij start IS & 222 & 12,4 & 0,18 \\
Gewicht bij start IS (kg) & 11,7 & 43,6 & 0,26 \\
Spekdikte bij start IS (mm) & 47,6 & 3,5 & 12,5 \\
Gewichtsverlies inzet kraamstal-start IS (kg) & 3,3 & 101,5 & \\
Spekdikteverlies inzet kraamstal-start IS (mm) & 12,1 & 97,9 & \\
Toomgrootte bij start IS & & & \\
Toomgewicht bij start IS (kg) & & & \\
\hline
\end{tabular}

${ }^{1}$ Het progesterongehalte bij de 39 zeugen op het zetmeelrijke voer en de 38 zeugen op het vetrijke voer was respectievelijk 15,3 en $14,7 \mathrm{ng} / \mathrm{ml}(\mathrm{p}=0,59)$

Van de 79 zeugen die geïnsemineerd zijn, waren er 65 (is 82,3\%) drachtig op vier weken na inseminatie. Dit is vergelijkbaar met het onderzoek van Van der Peet-Schwering et al. (2015). Het percentage drachtige zeugen verschilde niet tussen de zeugen die het zetmeelrijke of vetrijke voer kregen tijdens de laatste 8 dagen van de 6-weekse lactatie waarin ze dragend en lacterend waren. Ook Van den Brand et al. (2000b) vonden geen effect op het percentage drachtige zeugen van het verstrekken van een zetmeelrijk of een vetrijk voer tijdens de lactatie, het interval spenen-bronst en de eerste 35 dagen van de dracht.

Het percentage drachtige zeugen werd wel beïnvloed door het voerniveau begin dracht. Het was bijna $20 \%$ hoger bij de zeugen die op het hoge voerniveau werden gevoerd $(92,5$ versus $71,8 \%$ bij de zeugen op respectievelijk het hoge en standaard voerniveau begin dracht). Van de 14 zeugen die niet drachtig waren vier weken inseminatie zijn er zes binnen 16 dagen na inseminatie (is binnen 6 dagen na spenen) teruggekomen. Van deze zes zeugen hebben er vijf geen eisprong gehad (ze hadden geen corpora lutea op de dag van spenen maar hadden follikels van 4,3 mm). Deze vijf zeugen ( $3 \mathrm{kregen}$ zetmeelrijk voer en 2 vetrijk voer) waren bij toeval allemaal ingedeeld bij het standaard voerniveau. Als deze vijf zeugen als niet berig worden beschouwd, is het percentage drachtige zeugen $10 \%$ lager op het standaard voerniveau dan op het hoge voerniveau $(82,4$ versus $92,5 \% ; p=0,18)$. Mogelijk heeft herstel van conditieverlies aan het begin van de dracht na een periode van conditieverlies een hogere prioriteit dan een goede ontwikkeling van de embryo's en was het voerniveau van 2,8 $\mathrm{kg}$ te laag om voldoende nutriënten over te houden voor de ontwikkeling van de embryo's. 
Vijf zeugen hebben bronstverschijnselen laten zien en zijn daarom geïnsemineerd, maar er heeft geen eisprong plaats gevonden. Het progesterongehalte in de melk van deze vijf zeugen, de overige negen niet drachtige zeugen en de 65 drachtige zeugen was respectievelijk 4,4, 15,6 en 15,7 ng/ml. Dit betekent dat de vijf berige zeugen zonder eisprong een vergelijkbaar progesterongehalte in de melk hadden als de zeugen die niet berig zijn geworden na IS (4,9 ng/ml). Ook Gerritsen (2008) zag bronstverschijnselen bij zeugen terwijl ze niet geövuleerd hadden. Zij gaf aan dat er bij deze zeugen sprake was van regressie van de follikels voordat ze ovuleerden of van cysteuze follikels.

\section{Worpgrootte in de volgende worp}

Voor een goede worpgrootte is het belangrijk dat er bij ovulatie voldoende goed ontwikkelde follikels zijn, zodat voldoende eicellen van een goede kwaliteit vrijkomen. Voor een goede follikelontwikkeling zijn hoge insuline en IGF-1 niveaus belangrijk (Cosgrove and Foxcroft, 1996; Wientjes, 2013). De insuline en IGF-1 productie kunnen worden gestimuleerd door de zeugen op een hoog voerniveau te voeren (Zak et al., 1997; Prunier et al., 2000) en door insuline stimulerende voercomponenten zoals zetmeel en suikers (Wientjes, 2013) te verstrekken. Om een goede follikelontwikkeling te stimuleren zijn alle zeugen in ons onderzoek daarom voor inseminatie op een hoog voerniveau $(7,5 \mathrm{~kg} / \mathrm{dag})$ gevoerd. Naast voerniveau heeft ook de conditie van de zeugen een invloed op de productie van insuline en IGF-1 en daarmee op de follikelontwikkeling. Uit onderzoek van Kemp en Soede (2012) bleek dat bij zeugen die veel gewicht verliezen tijdens de lactatie, de follikel ontwikkeling is geremd waardoor minder ontwikkelde follikels worden gerekruteerd. In ons onderzoek was het gewichtsverlies van inzet kraamstal tot start IS op dag 27 na werpen vergelijkbaar bij de zeugen die daarna een zetmeelrijk of vetrijk voer kregen.

Het aantal totaal geboren biggen en het aantal levend en dood geboren biggen in de volgende worp verschilden niet significant tussen de zeugen die de laatste 8 dagen van de voorgaande 6-weekse lactatie, waarin ze ook drachtig waren, een zetmeelrijk of een vetrijk voer kregen. Dit komt overeen met de resultaten gevonden door Van den Brand et al. (2000b) en Athorn et al. (2013). Zij zagen geen verschil in embryonale overleving tussen zeugen en gelten die een zetmeelrijk of vetrijk voer kregen tijdens de vroege dracht. Athorn et al. (2013) hebben op dag 5 en 15 van de dracht het progesterongehalte in het bloed gemeten bij gelten. Op dag 5 van de dracht vonden zij geen verschil in progesterongehalte tussen de gelten die het zetmeelrijke of het vetrijke voer kregen. Echter, op dag 15 van de dracht was het progesterongehalte duidelijk hoger bij de gelten die het vetrijke voer kregen. Vet is een precursor voor cholesterol en de productie van steroïden en dit heeft mogelijk de progesteronproductie verhoogd (Athorn et al., 2013). Het hogere progesterongehalte resulteerde niet in een hogere embryonale overleving. In ons onderzoek is het progesterongehalte in de melk gemeten op dag 9 à 10 van de dracht bij zeugen in een negatieve energiebalans vanwege lactatie. De zeugen die het zetmeelrijke voer kregen tijdens de laatste 8 dagen van de lactatie en die vier weken na inseminatie drachtig waren hadden een hoger progesterongehalte in de melk dan de zeugen die het vetrijke voer kregen en vier weken na inseminatie drachtig waren $(16,2$ versus $15,3 \mathrm{ng} / \mathrm{ml} ; \mathrm{p}=0,07)$. Deze resultaten zijn tegengesteld met die van Athorn et al. (2013) maar komen wel overeen met die van Kemp et al. (1995). Zij gaven zeugen van werpen tot 35 dagen dracht een zetmeelrijk of vetrijk voer en vonden de eerste 10 dagen van de dracht significant hogere progesterongehalten in het bloed bij de zeugen die het zetmeelrijke voer kregen. Van den Brand et al. (2000b) deden een vergelijkbare studie als Kemp et al. (1995) en vonden geen verschil in progesterongehalte tussen zeugen die het zetmeelrijke of vetrijke voer kregen. Langendijk et al. (2008) vonden een positieve relatie tussen IGF1 concentratie in het bloed na insemineren en het progesterongehalte in het bloed. IGF-1 neemt toe bij een hoog voerniveau, m.n. bij zetmeelrijke voeders (Van den Brand, 2000). In ons onderzoek kregen de zeugen ca. 7,5 EW van het zetmeelrijke en vetrijke voer na inseminatie. Mogelijk is het stimulerende effect van het zetmeelrijke voer op IGF-1 en progesteron groter dan het effect van meer vet in het voer op de productie van steroïden en progesteron. Daarnaast waren de drachtige zeugen in ons onderzoek lacterend en in een negatieve energiebalans. Mogelijk heeft dit ook een rol gespeeld. Het hogere progesterongehalte in de melk bij de zeugen die het zetmeelrijke voer kregen resulteerde niet in meer levend geboren biggen in de volgende worp. 


\section{Groei en voeropname van de biggen}

Bij de start IS op dag 27 na werpen wogen de biggen 8,2 kg. Dat komt overeen met het gemiddeld speengewicht van de biggen op VIC Sterksel. Van dag 27 tot dag 34 na werpen (de IS periode waarin de biggen 10 uur per dag van de zeug gescheiden waren) namen de biggen 0,27 kg voer op (dat is 39 gram per dag) en groeiden de biggen $164 \mathrm{~g} / \mathrm{d}$. In recent uitgevoerde proeven op VIC Sterksel bleek dat biggen die op dag 27 gespeend worden, de eerste week na spenen eveneens circa $160 \mathrm{~g} / \mathrm{d}$ groeien. De voeropname van deze biggen was echter $180 \mathrm{~g} / \mathrm{d}$. Dat is ruim vier keer hoger dan de voeropname van biggen van dezelfde leeftijd die niet gespeend zijn en die 10 uur per dag van de zeug gescheiden waren. De niet gespeende biggen hebben tijdens de IS periode dus weinig vast voer opgenomen. In het onderzoek van Van der Peet-Schwering et al. (2015) namen de biggen tijdens de IS periode $0,29 \mathrm{~kg}$ voer op. In hun onderzoek kregen de biggen van dag 27 tot dag 34 het voer via een andere voerbak (4-vaks droogvoerbak) verstrekt dan tot dag 27 (rond bijzetbakje). De wisseling van voerbak verklaarde waarschijnlijk deels de lage voeropname van de biggen. In dit onderzoek kregen de biggen van dag 27 tot dag 34 daarom het voer niet alleen via een 4-vaks droogvoerbak verstrekt maar tijdens de afwezigheid van de zeug ook via een rond bijzetbakje. Dit heeft de voeropname van de biggen echter niet gestimuleerd. Melk opnemen bij de zeugen heeft blijkbaar de voorkeur boven het opnemen van vast voer.

Bij spenen op 42 dagen na geboorte wogen de biggen gemiddeld $11,5 \mathrm{~kg}$. Dit gewicht komt ongeveer overeen met biologische biggen die ook op 42 dagen na geboorte gespeend worden (Bikker et al., 2011) en met het gewicht van biggen van 42 dagen oud, die op dag 27 na geboorte gespeend zijn (Van der Peet-Schwering et al., 2014). Het toepassen van IS in combinatie met later spenen lijkt dus geen nadelig effect te hebben op de groei van de biggen tijdens de laatste twee weken van de zes weekse zoogperiode, maar het heeft ook geen positief effect op de groei.

Bij de biggen van de zeugen op het vetrijke voer kwam meer diarree voor dan bij de biggen van de zeugen op het zetmeelrijke voer. Het vetgehalte in de melk bij de zeugen op het zetmeelrijke en vetrijke voer was niet significant verschillend, dus dit verklaart niet het hogere aantal biggen met diarree. Het percentage middellangketenige vetzuren in het melkvet was echter hoger ( 48,5 versus $42,9 \%)$ en het percentage langketenige vetzuren lager $(49,6$ versus $55,1 \%)$ bij de zeugen die het zetmeelrijke voer kregen. Zuigende biggen kunnen middellangketenige vetzuren beter verteren dan langketenige vetzuren (Pettigrew et al., 1989; Gu and Li, 2003) en dit verklaart waarschijnlijk het lagere aantal biggen met diarree bij het zetmeelrijke voer. 


\section{Conclusies}

De belangrijkste conclusies uit het onderzoek zijn:

Zetmeelrijk versus vetrijk lactovoer tijdens laatste 8 dagen van de 6-weekse lactatie:

- Van de 103 zeugen die ingezet zijn in het onderzoek zijn er 79 (is 76,7\%) binnen 6 dagen na start van IS berig geworden. Dit percentage was vergelijkbaar bij de zeugen die daarna het zetmeelrijke of vetrijke lactovoer kregen.

- Van de 79 zeugen die geïnsemineerd zijn, waren er 65 (is 82,3\%) drachtig vier weken na inseminatie. Dit percentage was vergelijkbaar bij de zeugen die het zetmeelrijke of vetrijke lactovoer kregen.

- Tijdens de laatste 8 dagen van de 6-weekse lactatie was er een tendens tot minder gewichtsverlies bij de zeugen op het zetmeelrijke voer ( 9 versus $13 \mathrm{~kg} ; \mathrm{p}=0,11$ ).

- Het speengewicht en de groei en de voeropname van de biggen tijdens de laatste 8 dagen van de 6-weekse zoogperiode waren vergelijkbaar bij de zeugen die het zetmeelrijke of het vetrijke lactovoer kregen.

- De melkproductie van de zeugen bleef tijdens de laatste 8 dagen van de 6-weekse lactatie op een hoog niveau van ca. $11 \mathrm{~kg} / \mathrm{d}$.

- $\quad$ Er waren tussen de zeugen die het zetmeelrijke of vetrijke lactovoer kregen geen significante verschillen in de gehalten aan droge stof, ruw eiwit, vet en lactose in de melk op de dag van spenen. Er waren wel verschillen in de vetzuursamenstelling.

- Het progesterongehalte in de melk van de drachtige zeugen tendeerde naar hoger bij de zeugen die het zetmeelrijke lactovoer kregen $(16,2$ versus $15,3 \mathrm{ng} / \mathrm{ml} ; \mathrm{p}=0,07)$.

- $\quad$ Bij de biggen van de zeugen op het vetrijke voer kwam meer diarree voor tijdens de laatste 8 dagen van de 6-weekse lactatie dan bij de biggen van de zeugen op het zetmeelrijke voer.

- Het totaal aantal geboren biggen en het aantal levend en dood geboren biggen in de volgende worp verschilden niet significant tussen de zeugen die het zetmeelrijke of vetrijke lactovoer kregen. Het geboortegewicht van de biggen was numeriek, maar niet significant, hoger bij de zeugen die het zetmeelrijke lactovoer kregen $(1,35$ versus $1,27 \mathrm{~kg} ; \mathrm{p}=0,12)$.

Hoog versus standaard voerniveau vanaf spenen tot 34 dagen dracht:

- Het percentage drachtige zeugen vier weken na inseminatie was hoger bij de zeugen die op het hoge voerniveau werden gevoerd tot 34 dagen dracht dan bij de zeugen die op het standaard voerniveau werden gevoerd.

- Van spenen op dag 42 na werpen tot inzet kraamstal namen de zeugen op het hoge voerniveau meer toe in gewicht dan de zeugen op het standaard voerniveau $(67,8$ versus $59,0 \mathrm{~kg} ; \mathrm{p}=0,01)$. Er was geen duidelijk verschil in spekdikte toename tussen de zeugen op het hoge of standaard voerniveau (4,5 versus $4,1 \mathrm{~mm} ; \mathrm{p}=0,29)$.

- Het totaal aantal geboren biggen, het aantal levend en dood geboren biggen en het geboortegewicht van de biggen verschilde niet significant tussen de zeugen die een hoog of standaard voerniveau kregen tot 34 dagen dracht.

Overall kan geconcludeerd worden dat zeugen tijdens de laatste 8 dagen van een 6-weekse zoogperiode waarin ze ook drachtig zijn op een hoog voerniveau gevoerd moeten worden. Ter vermindering van het gewichtsverlies van de zeugen heeft een zetmeelrijk lactovoer de voorkeur boven een vetrijk lactovoer. Daarnaast zorgt een hoog voerniveau $(3,5 \mathrm{~kg} / \mathrm{d}$ ) van spenen tot 34 dagen dracht voor een beter conditieherstel tijdens de dracht dan het standaard voerniveau $(2,8 \mathrm{~kg} / \mathrm{d})$. 


\section{Literatuur}

Athorn R.Z., P. Stott, E.G. Bouwman, A.C. Edwards, M. A. Blackberry, G.B. Martin and P. Langendijk, 2013. Feeding level and dietary energy source have no effect on embryo survival in gilts, despite changes in systematic progesterone levels. Animal Production Science, 53, 30-37.

Bergsma, R., E. Kanis, M.W.A. Verstegen, C.M.C. van der Peet-Schwering and E.F. Knol. 2009. Lactation efficiency as a result of body composition dynamics and feed intake in sows. Livestock Science, 125, 208-222.

Bikker, P., C.M.C. van der Peet-Schwering, G.P. Binnendijk. 2011. Opname van gras- en mengkuil door dragende biologische zeugen. Rapport 439, Wageningen UR Livestock Research, Wageningen.

Brand, van den H. 2000. Energy partitioning and reproduction in primiparous sows: effects of dietary energy source. PhD thesis, Wageningen University, Wageningen.

Brand, van den H., S.J. Dieleman, N.M. Soede and B. Kemp. 2000. Dietary energy source at two feeding levels during lactation of primiparous sows: I. Effects on glucose, insulin, and luteinizing hormone and on follicle development, weaning-to-estrus interval, and ovulation rate. Journal of Animal Science, 78, 396-404.

Brand, van den H., M.J.W. Heetkamp, N.M. Soede, J.W. Schrama and B. Kemp. 2000a. Energy balance of lactating primiparous sows as affected by feeding level and dietary energy source. Journal of Animal Science, 78, 1520-1528.

Brand, van den H., N.M. Soede and B. Kemp. 2000b. Dietary energy source at two feeding levels during lactation of primiparous sows: II. Effects on periestrus hormone profiles and embryonal survival. Journal of Animal Science, 78, 405-411.

Cosgrove J.R. and G.R. Foxcroft. 1996. Nutrition and reproduction in the pig: Ovarian Aetiology. Animal Reproduction Science 42, 19, 13 I- 141.

Dyck, G. and J. Strain. 1983. Postmating Feeding Level Effects on Conception Rate and Embryonic Survival in Gilts. Canadian Journal of Animal Science, 63, 579-585.

Everts, H., M.C. Blok, B. Kemp, C.M.C. van der Peet-Schwering and C.H.M. Smits. 1995. Normen voor lacterende zeugen. CV-documentatierapport nr. 13.

Gerritsen, R., N.M. Soede, B.F.A. Laurenssen, P. Langedijk, S.J. Dielman and B.Kemp. 2008. Feeding level does not affect progesterone levels in intermittently suckled sows with lactational ovulation. Animal Reproduction Science, 103, 379-384.

Gerritsen, R. 2008. Lactational oestrus in sows. Follicle growth, hormone profiles and early pregnancy in sows subjected to intermittent suckling. PhD thesis, Wageningen University.

Gu, X. and D. Li. 2003. Fat nutrition and metabolism in piglets: a review. Animal Feed Science and Technology, 109, 151-170.

Hoving L.L., N.M. Soede, C.M.C. van der Peet-Schwering, E.A.M. Graat, H. Feitsma and B. Kemp. 2011. An increased feed intake during early pregnancy improves sow bodyweight recovery and increases litter size in young sows. Journal of Animal Science, 89, 3543-3550. 
Kemp, B., N.M. Soede, F.A. Helmond and M.W. Bosch. 1995. Effects of energy source in the diet on reproductive hormones and insulin during lactation and subsequent estrus in multiparous sows. Journal of Animal Science, 73, 3022-3029.

Kemp B. and N.M. Soede, 2012. Should weaning be the start of the reproductive cycle in hyper-prolific sows? A physiologic view. Reproduction Domestic Animals, 47 (suppl. 4), 320-326.

Langendijk, P., H. van den Brand, R. Gerritsen, H. Quesnel, N.M. Soede and B. Kemp. 2008. Porcine luteal function in relation to IGF-1 levels following ovulation during lactation or after weaning. Reproduction in Domestic Animals, 43, 131-136.

Nelssen, J., A. Lewis, E. Peo, B. and Moser. 1985. Effect of Source of Dietary Energy and Energy Restriction During Lactation on Sow and Litter Performance. Journal of animal science, 60, 171-178.

Oude Voshaar, J.H. 1995. Statistiek voor onderzoekers. Wageningen Pers, Wageningen.

Peet-Schwering, C. M. C. van der, J.M. Rommers, L.M.P Troquet, N.M. Soede. 2015. Effect van voerniveau bij drachtige lacterende zeugen op reproductie en conditie. Rapport 861, Wageningen UR Livestock Research, Wageningen.

Peet-Schwering, C.M.C. van der, L.M.P Troquet, G.P. Binnendijk and E. Knol. 2013. Effect van genetische aanleg en geboortegewicht op de technische resultaten van biggen en vleesvarkens. Rapport 724, Wageningen UR Livestock Research, Wageningen.

Peet-Schwering, C.M.C. van der, L.M.P Troquet, G.P. Binnendijk, R.H. Vogelzang and E. Knol. 2014. Voerstrategie voor vleesvarkens in relatie tot genetische aanleg en geboortegewicht. Rapport 816, Wageningen UR Livestock Research, Wageningen.

Pettigrew, J.E., M.D. Tokach, M. Overland and R.L. Moser. 1989. Use of supplemental fat in swine diets explored. Feedstuffs $61,18-28$.

Prunier A. and H. Quesnel. 2000. Influence of the nutritional status on ovarian development in female pigs. Animal Reproduction Science, 60-61, 185-197.

Roelofs, J.B., F.J. van Eerdenburg, W. Hazeleger, N.M. Soede and B. Kemp. 2006. Relationship between progesterone concentrations in milk and blood and time of ovualtion in dairy cattle. Animal Reproduction Science, 91, 337-343.

Rommers, J.M., C.M.C. van der Peet-Schwering, N.M. Soede en R. Gerritsen. 2014. Literatuurstudie naar de voeding van lacterende zeugen in groepshuisvesting. Rapport 759. Wageningen UR Livestock Research, Wageningen.

Soede N.M., B. Laurenssen, M. Abrahamse-Berkenveld, R. Gerritsen, N. Dirk-Kuijken, P. Langendijk, B. Kemp. 2012. Timing of lactational oestrus in intermittens suckling regimes: consequences for sow fertility. Animal Reproduction Science, 130, 74-81.

Toplis, P., M. Ginesi, and A. Wrathall. 1983. The Influence of High Food Levels in Early Pregnancy on Embryo Survival in Multiparous Sows. Animal Production, 37, 45-48.

Wientjes J.G.M. 2013. Piglet birth weight and litter uniformity. Importance of pre-mating nutritional and metabolic conditions. PhD thesis Wageningen University, Wageningen, The Netherlands. ISBN 978-94-6173-502-7.

Zak, L.J., X. Xu, R. T. Hardin and G. R. Foxcroft. 1997. Impact of different patterns of feed intake during lactation in the primiparous sow on follicular development and oocyte maturation. Journal of Reproduction and Fertility, 110, 99-106. 


\section{Bijlage 1 Grondstoffen (\%)- en nutriënten samenstelling van de proefvoeders}

\begin{tabular}{|c|c|c|c|}
\hline \multirow{2}{*}{\multicolumn{2}{|c|}{ GERST GESCHOOND }} & Zetmeelrijk & Vetrijk \\
\hline & & 14.500 & 15.880 \\
\hline \multicolumn{2}{|c|}{ TARWE GESCHOOND } & 11.400 & 12.490 \\
\hline \multicolumn{2}{|c|}{ MAIS (AO-EU) } & 19.323 & 20.001 \\
\hline \multicolumn{2}{|c|}{ MAISZETMEEL } & 13.500 & \\
\hline \multicolumn{2}{|c|}{ TARWEGRIES } & 12.010 & 14.330 \\
\hline \multicolumn{2}{|c|}{ PALMPITSCHILFERS } & 2.500 & 2.740 \\
\hline \multicolumn{2}{|c|}{ RAAPZAADSCHROOT } & 4.000 & 4.380 \\
\hline \multicolumn{2}{|c|}{ BRAZ SOYASCHROOT HIPRO } & 10.500 & 11.500 \\
\hline \multicolumn{2}{|c|}{ SOYAHULLEN 320-360RC } & 2.000 & 2.190 \\
\hline \multicolumn{2}{|c|}{ MELASSE-RIET } & 2.000 & 2.190 \\
\hline \multicolumn{2}{|c|}{ BIETENPULP $<10$ su } & 2.000 & 2.190 \\
\hline \multicolumn{2}{|c|}{ PALMOLIE } & 0.850 & 4.430 \\
\hline \multicolumn{2}{|l|}{ SOJAOLIE } & 0.950 & 2.790 \\
\hline \multicolumn{2}{|l|}{ KRIJT } & 1.520 & 1.670 \\
\hline \multicolumn{2}{|c|}{ MONO-CAL-FOSFAAT } & 0.660 & 0.730 \\
\hline \multicolumn{2}{|c|}{ NATRIUMBICARBONAAT } & 0.260 & 0.280 \\
\hline \multicolumn{2}{|c|}{ ZOUT } & 0.460 & 0.500 \\
\hline \multicolumn{2}{|c|}{ METHIONINE (DL,99\%) } & 0.064 & 0.067 \\
\hline \multicolumn{2}{|c|}{ TRYPTOFAAN (L,98\%) } & 0.022 & 0.022 \\
\hline \multicolumn{2}{|c|}{ L-LYSINE HCL } & 0.330 & 0.350 \\
\hline \multicolumn{2}{|c|}{ L-THREONINE } & 0.121 & 0.130 \\
\hline \multicolumn{2}{|c|}{ Vitamine } & 0.130 & 0.190 \\
\hline \multicolumn{2}{|c|}{ START/BL.15CU } & 0.400 & 0.400 \\
\hline \multicolumn{2}{|c|}{ FYTASE } & 0.500 & 0.550 \\
\hline EW & & 1.08 & 1.18 \\
\hline $\operatorname{Re}$ & $\mathrm{g}$ & 136.818 & 149.805 \\
\hline Rvet & $\mathrm{g}$ & 40.306 & 95.744 \\
\hline RC & $g$ & 49.338 & 54.567 \\
\hline As & $\mathrm{g}$ & 57.068 & 62.721 \\
\hline Vocht & $\mathrm{g}$ & 118.708 & 111.997 \\
\hline Zetmeel & $\mathrm{g}$ & 415.013 & 325.640 \\
\hline Suiker & $g$ & 39.009 & 43.300 \\
\hline NSP & $\mathrm{g}$ & 199.236 & 217.787 \\
\hline VNSP & $\mathrm{g}$ & 120.139 & 132.938 \\
\hline $\mathrm{Ca}$ & $\mathrm{g}$ & 8.717 & 9.551 \\
\hline$P$ & $\mathrm{~g}$ & 5.012 & 5.521 \\
\hline vP & $\mathrm{g}$ & 3.3 & 3.6 \\
\hline $\mathrm{Na}$ & $g$ & 2.590 & 2.811 \\
\hline $\mathrm{K}$ & g & 7.570 & 8.395 \\
\hline $\mathrm{Cl}$ & g & 4.289 & 4.651 \\
\hline $\mathrm{EB}$ & meq & 189.31 & 210.25 \\
\hline DVLYSV & $\mathrm{g}$ & 7.545 & 8.242 \\
\hline DVMETV & $\mathrm{g}$ & 2.410 & 2.625 \\
\hline $\mathrm{DVM}+\mathrm{CV}$ & $\mathrm{g}$ & 4.237 & 4.656 \\
\hline DVTHRV & g & 4.580 & 5.057 \\
\hline DVTRPV & $\mathrm{g}$ & 1.416 & 1.559 \\
\hline
\end{tabular}




\section{Bijlage 2 Voeropname zeugen per pariteit}

Voeropname $(\mathrm{kg} / \mathrm{d})$ per pariteit tijdens de 6-weekse lactatie van zeugen; tot start voerbehandeling op dag 34 na werpen kregen alle zeugen hetzelfde lactovoer; daarna kregen de zeugen tot spenen op dag 42 een zetmeelrijk of vetrijk lactovoer verstrekt. Weergegeven zijn de LSM \pm s.e.

\begin{tabular}{lcccc}
\hline Pariteit & 2 & $3+4$ & $5-7$ & P-waarde \\
\hline Aantal zeugen & 20 & 35 & 48 & \\
Worpnummer & $2,0 \pm 0,0$ & $3,5 \pm 0,5$ & $5,9 \pm 0,8$ & \\
& & & & \\
Voeropname (kg/dag): & & & & \\
- inleg kraamhok tot werpen & $2,70 \pm 0,04$ & $2,75 \pm 0,03$ & $2,73 \pm 0,03$ & 0,63 \\
- werpen tot start IS & $6,16^{\times} \pm 0,12$ & $6,41^{\mathrm{y}} \pm 0,09$ & $6,15^{\times} \pm 0,08$ & 0,06 \\
- start IS tot start voerbehandeling & $5,75^{\times} \pm 0,20$ & $6,29^{\mathrm{y}} \pm 0,15$ & $6,08^{\times \mathrm{y}} \pm 0,13$ & 0,09 \\
- start voerbehandeling tot spenen & $6,12 \pm 0,33$ & $6,54 \pm 0,25$ & $6,45 \pm 0,22$ & 0,58 \\
\hline
\end{tabular}

$x, y$ Gemiddelden met een verschillende letter binnen een rij geven aanwijzing voor verschil $(p<0,10)$

Voeropname $(\mathrm{kg} / \mathrm{d})$ per behandeling en per pariteit tijdens de 6-weekse lactatie van zeugen; tot start voerbehandeling op dag 34 na werpen kregen alle zeugen hetzelfde lactovoer; daarna kregen de zeugen tot spenen op dag 42 een zetmeelrijk of vetrijk lactovoer verstrekt.

\begin{tabular}{|c|c|c|c|c|c|c|c|}
\hline \multirow{2}{*}{$\begin{array}{l}\text { Pariteit } \\
\text { Voersamenstelling }\end{array}$} & \multicolumn{2}{|l|}{2} & \multicolumn{2}{|c|}{$3+4$} & \multicolumn{2}{|c|}{$5+6+7$} & \multirow{2}{*}{$\begin{array}{l}\text { P-waarde } \\
\text { interactic }\end{array}$} \\
\hline & zetmeel & vet & zetmeel & vet & zetmeel & vet & \\
\hline Aantal zeugen & 10 & 10 & 17 & 18 & 25 & 23 & \\
\hline Worpnummer & 2,0 & 2,0 & 3,5 & 3,5 & 5,8 & 5,9 & \\
\hline $\begin{array}{l}\text { Voeropname }(\mathrm{kg} / \mathrm{dag}) \text { : } \\
\text { - inleg kraamhok tot werpen }\end{array}$ & $2,75^{\mathrm{ab}}$ & $2,64^{a}$ & $2,68^{a b}$ & $2,82^{b}$ & $2,73^{\mathrm{ab}}$ & $\underset{b}{2,72^{a}}$ & 0,05 \\
\hline - werpen tot start IS & $6,36^{x y}$ & $5,95^{x}$ & $6,30^{x y}$ & $6,53^{y}$ & $6,21^{x}$ & $6,09^{x}$ & 0,07 \\
\hline - start IS tot start voerbehandeling & 5,65 & 5,84 & 6,09 & 6,48 & 5,98 & 6,18 & 0,86 \\
\hline - start voerbehandeling tot spenen & 6,02 & 6,21 & 6,66 & 6,42 & 6,85 & 6,05 & 0,39 \\
\hline
\end{tabular}

$\mathrm{a}, \mathrm{b}$ Gemiddelden met een verschillende letter binnen een rij zijn verschillend $(p<0,05)$

$x, y$ Gemiddelden met een verschillende letter binnen een rij geven aanwijzing voor verschil $(p<0,10)$ 


\section{Bijlage 3 Gewicht en spekdikte per pariteit}

Gewichten en spekdikten per pariteit van de zeugen tijdens de 6-weekse lactatie; tot start voerbehandeling op dag 34 na werpen kregen alle zeugen hetzelfde lactovoer; daarna kregen de zeugen tot spenen op dag 42 een zetmeelrijk of vetrijk lactovoer verstrekt. Weergegeven zijn LSM \pm s.e.

\begin{tabular}{lcccc}
\hline Pariteit & 2 & $3+4$ & $5-7$ & P-waarde \\
\hline Aantal zeugen & 20 & 35 & 48 & \\
& & & & \\
Gewicht (kg): & & & & \\
- bij inleg kraamhok & $246^{\mathrm{a}} \pm 3,9$ & $263^{\mathrm{b}} \pm 2,9$ & $290^{\mathrm{c}} \pm 2,5$ & $<0,0001$ \\
- bij start IS op dag 27 & $200^{\mathrm{a}} \pm 3,6$ & $218^{\mathrm{b}} \pm 2,7$ & $250^{\mathrm{c}} \pm 2,3$ & $<0,0001$ \\
- bij start voerbehandeling op dag 34 & $199^{\mathrm{a}} \pm 4,0$ & $219^{\mathrm{b}} \pm 3,0$ & $255^{\mathrm{c}} \pm 2,6$ & $<0,0001$ \\
- bij spenen op dag 42 & $187^{\mathrm{a}} \pm 3,9$ & $207^{\mathrm{b}} \pm 2,9$ & $242^{\mathrm{c}} \pm 2,5$ & $<0,0001$ \\
& & & & \\
Spekdikte (mm): & & & & 0,09 \\
- bij inleg kraamhok & $15,7^{\mathrm{xy}} \pm 0,6$ & $15,1^{\mathrm{x}} \pm 0,4$ & $16,3^{\mathrm{y}} \pm 0,4$ & 0,004 \\
- bij start IS op dag 27 & $11,8^{\mathrm{a}} \pm 0,5$ & $11,7^{\mathrm{a}} \pm 0,4$ & $13,4^{\mathrm{b}} \pm 0,3$ & 0,005 \\
- bij start voerbehandeling op dag 34 & $10,8^{\mathrm{a}} \pm 0,5$ & $10,7^{\mathrm{a}} \pm 0,4$ & $12,4^{\mathrm{b}} \pm 0,3$ & 0,003 \\
\hline
\end{tabular}

$a, b, c$ Gemiddelden met een verschillende letter binnen een rij zijn verschillend $(p<0,05)$

$x, y$ Gemiddelden met een verschillende letter binnen een rij geven aanwijzing voor verschil $(p<0,10)$

Gewichten en spekdikten (LSM) per behandeling en pariteit van de zeugen tijdens de 6-weekse lactatie; tot start voerbehandeling op dag 34 na werpen kregen alle zeugen hetzelfde lactovoer; daarna kregen de zeugen tot spenen op dag 42 een zetmeelrijk of vetrijk lactovoer verstrekt.

\begin{tabular}{|c|c|c|c|c|c|c|c|}
\hline \multirow{2}{*}{ Pariteit } & \multicolumn{2}{|l|}{2} & \multicolumn{2}{|c|}{$3+4$} & \multicolumn{2}{|c|}{$5+6+7$} & \multirow{2}{*}{$\begin{array}{l}\text { P-waarde } \\
\text { interactie }\end{array}$} \\
\hline & zetmeel & vet & zetmeel & vet & zetmeel & vet & \\
\hline Aantal zeugen & 10 & 10 & 17 & 18 & 25 & 23 & \\
\hline \multicolumn{8}{|l|}{ Gewicht (kg): } \\
\hline - bij inleg kraamhok & 246 & 246 & 264 & 262 & 291 & 290 & 0,98 \\
\hline - bij start IS op dag 27 & 204 & 196 & 215 & 220 & 248 & 253 & 0,27 \\
\hline - bij start voerbehandeling op dag 34 & 202 & 197 & 216 & 222 & 251 & 259 & 0,41 \\
\hline - bij spenen op dag 42 & 191 & 184 & 203 & 210 & 241 & 244 & 0,35 \\
\hline \multicolumn{8}{|l|}{ Spekdikte $(\mathrm{mm})$ : } \\
\hline - bij inleg kraamhok & 15,9 & 15,5 & 14,9 & 15,2 & 16,5 & 16,2 & 0,86 \\
\hline - bij start IS op dag 27 & 12,1 & 11,4 & 11,5 & 11,8 & 13,1 & 13,7 & 0,53 \\
\hline - bij start voerbehandeling op dag 34 & 11,0 & 10,6 & 10,6 & 10,9 & 12,2 & 12,5 & 0,82 \\
\hline - bij spenen op dag 42 & 10,4 & 9,6 & 10,0 & 10,0 & 11,6 & 11,6 & 0,76 \\
\hline
\end{tabular}




\section{Bijlage 4 Gewicht- en spekdikte afname per pariteit}

Gewichtstoename/afname gedurende de lactatie voor zeugen van pariteit 2, pariteit 3+4 en pariteit 5 $\mathrm{t} / \mathrm{m}$ 7. $\mathrm{KOH}-\mathrm{IS}=$ inzet kraamstal tot start IS; IS-vsam= start IS tot start voerbehandeling; vsam-spn= start voerbehandeling tot spenen; totaal= inzet kraamstal tot spenen.

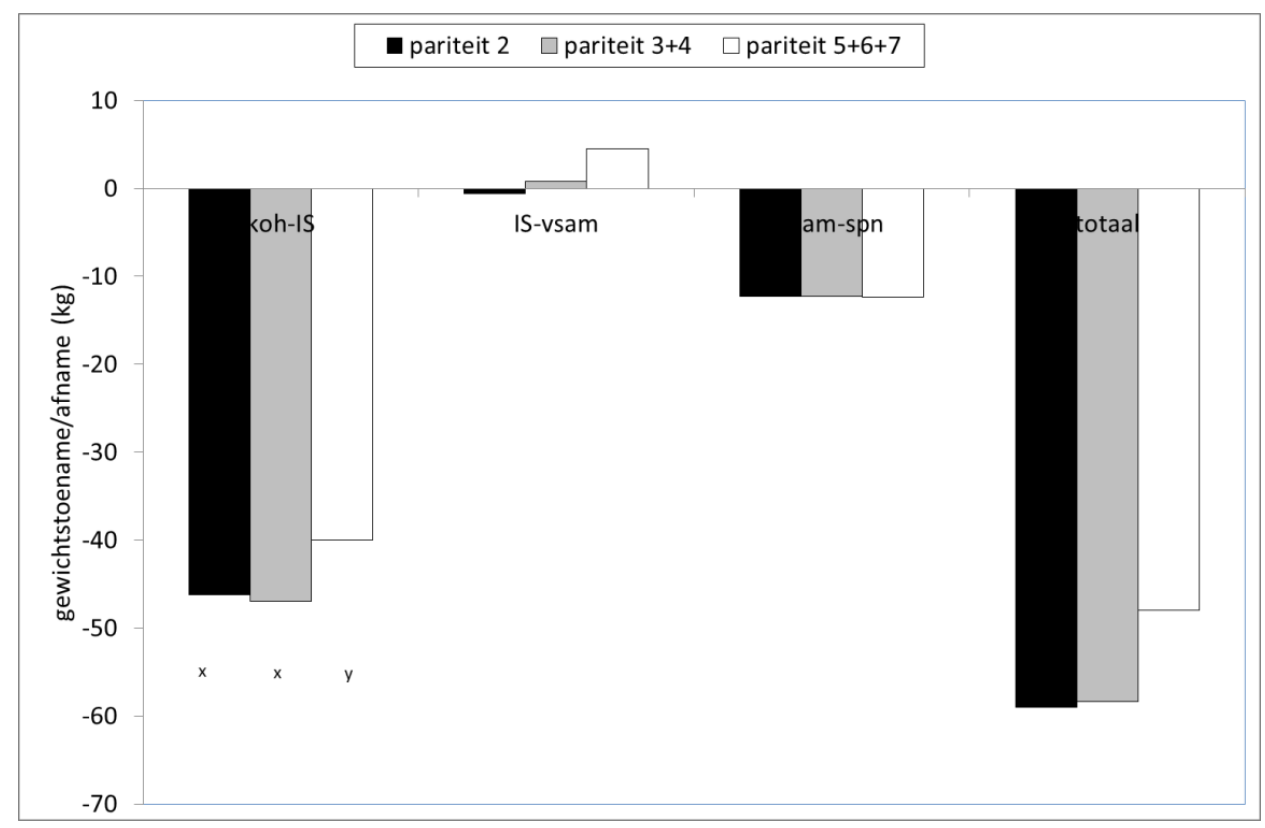

Spekdikte afname gedurende de lactatie voor zeugen van pariteit 2, pariteit $3+4$ en pariteit 5 t/m 7 . Koh-IS = van inzet kraamstal tot start IS, IS-vsam = van start IS tot start voerbehandeling; vsam$\mathrm{spn}=$ start voerbehandeling tot spenen; totaal= van inzet kraamstal tot spenen.

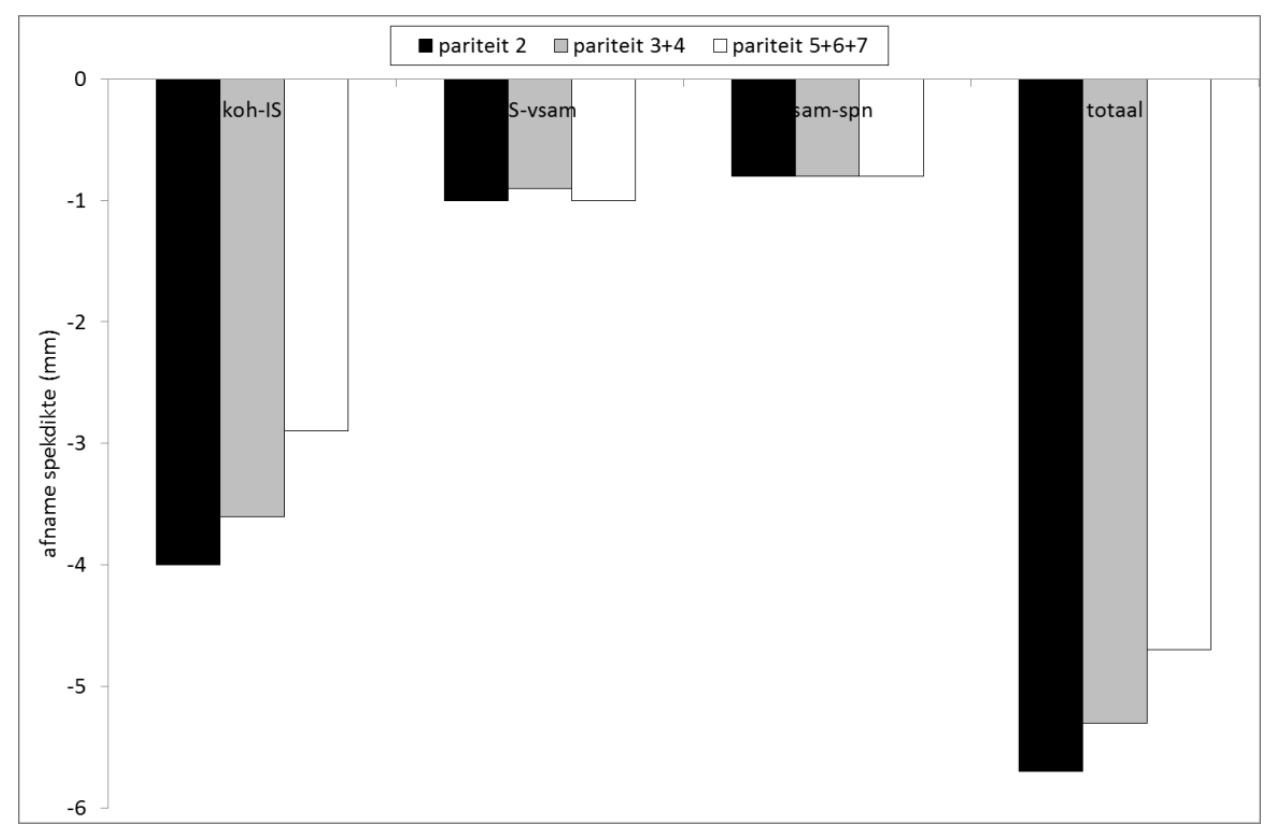




\section{Bijlage 5 Productieresultaten per pariteit}

Productieresultaten per pariteit tijdens de 6-weekse lactatie; tot start voerbehandeling op dag 34 na werpen kregen alle zeugen hetzelfde lactovoer; daarna kregen de zeugen tot spenen op dag 42 een zetmeelrijk of vetrijk lactovoer verstrekt. Weergegeven zijn LSM \pm s.e.

\begin{tabular}{lllll}
\hline Pariteit & 2 & $3+4$ & $5-7$ \\
& & & P- \\
waarde \\
\hline Totaal geboren biggen & $15,6^{\mathrm{a}} \pm 0,68$ & $17,7^{\mathrm{b}} \pm 0,51$ & $17,6^{\mathrm{b}} \pm 0,44$ & 0,03 \\
Levend geboren biggen & $14,8 \pm 0,62$ & $16,5 \pm 0,46$ & $15,9 \pm 0,40$ & 0,10 \\
Doodgeboren biggen & $0,7^{\mathrm{a}} \pm 0,32$ & $1,2^{\mathrm{ab}} \pm 0,24$ & $1,7^{\mathrm{b}} \pm 0,21$ & 0,05 \\
Geboortegewicht levend geboren & $1,42^{\mathrm{a}} \pm 0,042$ & $1,33^{\mathrm{ab}} \pm 0,031$ & $1,29^{\mathrm{b}} \pm 0,027$ & 0,04 \\
biggen (kg) & & & 0,20 \\
Beginaantal biggen & $13,8 \pm 0,47$ & $14,8 \pm 0,35$ & $14,7 \pm 0,31$ & 0,41 \\
Geboortegewicht beginaantal (kg) & $1,45 \pm 0,044$ & $1,39 \pm 0,033$ & $1,38 \pm 0,028$ & 0,07 \\
Aantal gespeende biggen & $12,4^{\mathrm{xy}} \pm 0,27$ & $12,6^{\mathrm{x}} \pm 0,20$ & $12,0^{\mathrm{y}} \pm 0,17$ & 0,05 \\
Speenleeftijd & $41,4^{\mathrm{xy}} \pm 0,4$ & $42,2^{\mathrm{y}} \pm 0,3$ & $41,3^{\mathrm{x}} \pm 0,3$ & 0,17 \\
Speengewicht (kg) & $11,0 \pm 0,29$ & $11,7 \pm 0,21$ & $11,5 \pm 0,19$ & 0,15 \\
Groei (g/d) & $232 \pm 6,1$ & $245 \pm 4,5$ & $246 \pm 3,9$ & 0,58 \\
Voeropname per big (kg) & $1,00 \pm 0,170$ & $1,21 \pm 0,117$ & $1,19 \pm 0,102$ & \\
\hline a,b Gemiddelden met een verschillende letter binnen een rij zijn verschillend $(\mathrm{p}<0,05)$ & & \\
x,y Gemiddelden met een verschillende letter binnen een rij geven aanwijzing voor verschil $(\mathrm{p}<0,10)$ &
\end{tabular}

Productieresultaten (LSM) per behandeling en pariteit tijdens de 6-weekse lactatie; tot start voerbehandeling op dag 34 na werpen kregen alle zeugen hetzelfde lactovoer; daarna kregen de zeugen tot spenen op dag 42 een zetmeelrijk of vetrijk lactovoer verstrekt.

\begin{tabular}{|c|c|c|c|c|c|c|c|}
\hline \multirow{2}{*}{$\begin{array}{l}\text { Pariteit } \\
\text { Voersamenstelling }\end{array}$} & \multicolumn{2}{|c|}{2} & \multicolumn{2}{|c|}{$3+4$} & \multicolumn{2}{|c|}{$5+6+7$} & \multirow{2}{*}{$\begin{array}{l}\text { P-waarde } \\
\text { interactie }\end{array}$} \\
\hline & Zetmeel & vet & zetmeel & vet & zetmeel & vet & \\
\hline Totaal geboren biggen & 15,2 & 15,9 & 18,4 & 17,0 & 18,0 & 17,3 & 0,44 \\
\hline Levend geboren biggen & 14,2 & 15,4 & 16,9 & 16,1 & 16,4 & 15,4 & 0,28 \\
\hline Doodgeboren biggen & 1,0 & 0,5 & 1,5 & 0,9 & 1,5 & 1,9 & 0,24 \\
\hline $\begin{array}{l}\text { Geboortegewicht levend } \\
\text { geboren biggen }(\mathrm{kg})\end{array}$ & 1,39 & 1,45 & 1,33 & 1,33 & 1,33 & 1,24 & 0,23 \\
\hline Beginaantal biggen & 13,1 & 14,5 & 14,6 & 15,0 & 14,8 & 14,7 & 0,40 \\
\hline $\begin{array}{l}\text { Geboortegewicht } \\
\text { beginaantal }(\mathrm{kg})\end{array}$ & 1,42 & 1,48 & 1,37 & 1,41 & 1,40 & 1,36 & 0,46 \\
\hline Aantal gespeende biggen & 12,5 & 12,4 & 12,5 & 12,7 & 12,0 & 12,0 & 0,79 \\
\hline Speenleeftijd & 41,7 & 41,1 & 42,2 & 42,2 & 41,3 & 41,2 & 0,83 \\
\hline Speengewicht (kg) & 11,0 & 11,1 & 11,9 & 11,6 & 11,7 & 11,4 & 0,70 \\
\hline Groei $(\mathrm{g} / \mathrm{d})$ & 228 & 235 & 249 & 241 & 249 & 243 & 0,58 \\
\hline Voeropname per big $(\mathrm{kg})$ & 0,99 & 1,01 & 1,30 & 1,11 & 1,22 & 1,16 & 0,83 \\
\hline
\end{tabular}




\section{Bijlage 6 Resultaten zuigende biggen per pariteit}

Resultaten van de zuigende biggen tijdens de 6-weekse lactatie per pariteit; tot start voerbehandeling op dag 34 na werpen kregen alle zeugen hetzelfde lactovoer; daarna kregen de zeugen tot spenen op dag 42 een zetmeelrijk of vetrijk lactovoer verstrekt. Weergegeven zijn LSM \pm s.e.

\begin{tabular}{|c|c|c|c|c|}
\hline Pariteit & 2 & $3+4$ & $5-7$ & P-waarde \\
\hline \multicolumn{5}{|l|}{ Geboorte tot start IS op dag 27} \\
\hline Beginaantal biggen & $13,8 \pm 0,47$ & $14,8 \pm 0,35$ & $14,7 \pm 0,31$ & 0,20 \\
\hline Geboortegewicht beginaantal $(\mathrm{kg})$ & $1,45 \pm 0,044$ & $1,39 \pm 0,033$ & $1,38 \pm 0,028$ & 0,41 \\
\hline Groei $(\mathrm{g} / \mathrm{d})$ & $255 \pm 5,4$ & $256 \pm 4,0$ & $252 \pm 3,5$ & 0,78 \\
\hline Voeropname per big $(\mathrm{kg})$ & $0,31 \pm 0,035$ & $0,34 \pm 0,024$ & $0,34 \pm 0,021$ & 0,74 \\
\hline \multicolumn{5}{|c|}{ Start IS tot start voerniveau op dag 34} \\
\hline Aantal biggen bij start IS & $12,4 \pm 0,27$ & $12,7 \pm 0,20$ & $12,1 \pm 0,17$ & 0,11 \\
\hline Gewicht bij start IS (kg) & $8,1 \pm 0,19$ & $8,3 \pm 0,14$ & $8,0 \pm 0,12$ & 0,23 \\
\hline Groei $(g / d)$ & $148 \pm 10,5$ & $171 \pm 7,8$ & $172 \pm 6,8$ & 0,15 \\
\hline Voeropname per big $(\mathrm{kg})$ & $0,24 \pm 0,042$ & $0,28 \pm 0,031$ & $0,28 \pm 0,027$ & 0,42 \\
\hline \multicolumn{5}{|l|}{ Start voerniveau tot spenen op dag 42} \\
\hline Aantal biggen bij start voerniveau & $12,4^{x y} \pm 0,27$ & $12,7^{x} \pm 0,20$ & $12,0^{y} \pm 0,17$ & 0,08 \\
\hline Gewicht bij start voerniveau (kg) & $9,2 \pm 0,21$ & $9,5 \pm 0,16$ & $9,2 \pm 0,14$ & 0,27 \\
\hline Aantal gespeende biggen & $12,4^{x y} \pm 0,27$ & $12,6^{x} \pm 0,20$ & $12,0^{y} \pm 0,17$ & 0,07 \\
\hline Gewicht bij spenen (kg) & $11,0 \pm 0,29$ & $11,7 \pm 0,21$ & $11,5 \pm 0,19$ & 0,17 \\
\hline Groei $(g / d)$ & $232^{\mathrm{a}} \pm 17,6$ & $276^{b} \pm 13,1$ & $291^{\mathrm{b}} \pm 11,4$ & 0,03 \\
\hline Voeropname per big $(\mathrm{kg})$ & $0,41 \pm 0,104$ & $0,59 \pm 0,077$ & $0,58 \pm 0,068$ & 0,35 \\
\hline
\end{tabular}

Resultaten van de zuigende biggen tijdens de 6-weekse lactatie per behandeling en pariteit.

\begin{tabular}{|c|c|c|c|c|c|c|c|}
\hline \multirow{2}{*}{ Pariteit } & \multicolumn{2}{|l|}{2} & \multicolumn{2}{|c|}{$3+4$} & \multicolumn{2}{|c|}{$5-7$} & \multirow[t]{2}{*}{ P-waarde } \\
\hline & zetmeel & vet & zetmeel & vet & zetmeel & vet & \\
\hline \multicolumn{8}{|l|}{ Geboorte tot start IS op dag 27} \\
\hline Beginaantal biggen & 13,1 & 14,5 & 14,6 & 15,0 & 14,8 & 14,7 & 0,40 \\
\hline Geboortegewicht beginaantal $(\mathrm{kg})$ & 1,42 & 1,48 & 1,37 & 1,41 & 1,40 & 1,36 & 0,46 \\
\hline Groei $(g / d)$ & 254 & 257 & 256 & 256 & 252 & 252 & 0,97 \\
\hline Voeropname per big $(\mathrm{kg})$ & 0,29 & 0,33 & 0,34 & 0,33 & 0,36 & 0,32 & 0,55 \\
\hline \multicolumn{8}{|c|}{ Start IS tot start voerniveau op dag 34} \\
\hline Aantal biggen bij start IS & 12,4 & 12,3 & 12,5 & 12,8 & 12,1 & 12,0 & 0,70 \\
\hline Gewicht bij start IS (kg) & 8,2 & 8,1 & 8,3 & 8,3 & 8,0 & 7,9 & 0,94 \\
\hline Groei $(g / d)$ & 141 & 156 & 178 & 163 & 173 & 172 & 0,49 \\
\hline Voeropname per big (kg) & 0,20 & 0,29 & 0,30 & 0,26 & 0,27 & 0,28 & 0,42 \\
\hline \multicolumn{8}{|c|}{ Start voerniveau tot spenen op dag 42} \\
\hline Gewicht bij start voerniveau (kg) & 9,2 & 9,2 & 9,6 & 9,5 & 9,3 & 9,1 & 0,91 \\
\hline Aantal gespeende biggen & 12,5 & 12,4 & 12,5 & 12,7 & 12,0 & 12,0 & 0,79 \\
\hline Gewicht bij spenen (kg) & 11,0 & 11,1 & 11,9 & 11,6 & 11,7 & 11,4 & 0,70 \\
\hline Groei $(\mathrm{g} / \mathrm{d})$ & 225 & 239 & 289 & 263 & 304 & 278 & 0,56 \\
\hline Voeropname per big (kg) & 0,48 & 0,34 & 0,66 & 0,51 & 0,60 & 0,55 & 0,83 \\
\hline
\end{tabular}




\section{Bijlage 7 Gewicht en spekdikte per pariteit in de volgende worp}

Gewichten en spekdikten van de zeugen in de volgende worp per pariteit; in de voorgaande lactatie zijn de zeugen geïnsemineerd tijdens een 6-weekse lactatie en kregen ze tijdens de laatste 8 dagen van de lactatie een zetmeelrijk of vetrijk voer verstrekt; na spenen werden de zeugen tot 34 dagen dracht volgens een hoog $(3,5 \mathrm{~kg} / \mathrm{d})$ of standaard $(2,8 \mathrm{~kg} / \mathrm{d})$ voerschema gevoerd.

\begin{tabular}{lcccc}
\hline Pariteit & 3 & $4+5$ & $6-8$ & P-waarde \\
\hline Aantal zeugen & 16 & 24 & 25
\end{tabular}

Gewicht $(\mathrm{kg})$ :

- inzet kraamstal vorige worp

- spenen vorige worp

- inzet kraamstal

- spenen op dag 27

$\begin{array}{llll}244^{\mathrm{a}} & 260^{\mathrm{b}} & 294^{\mathrm{c}} & <0,001 \\ 186^{\mathrm{a}} & 205^{\mathrm{b}} & 246^{\mathrm{c}} & <0,001 \\ 253^{\mathrm{a}} & 271^{\mathrm{b}} & 303^{\mathrm{c}} & <0,001 \\ 210^{\mathrm{a}} & 230^{\mathrm{b}} & 263^{\mathrm{c}} & <0,001\end{array}$

Gewichtstoename $(\mathrm{kg})$ :

- inzet kraamstal tot inzet kraamstal

- spenen tot inzet kraamstal

$\begin{array}{cccc}9,4 & 10,4 & 8,9 & 0,96 \\ 67,4^{x} & 65,4^{x} & 57,4^{y} & 0,05\end{array}$

Spekdikte $(\mathrm{mm})$ :

- inzet kraamstal vorige worp

- spenen vorige worp

- dag 28 dracht

- dag 77 dracht

- inzet kraamstal

- spenen op dag 27

Spekdiktetoename $(\mathrm{mm})$ :

- inzet kraamstal tot inzet kraamstal

- spenen tot inzet kraamstal

$15,6^{\mathrm{x}}$
$9,8^{\mathrm{a}}$
$10,7^{\mathrm{a}}$
12,7
$13,9^{\mathrm{a}}$
$10,9^{\mathrm{a}}$

$15,3^{x}$

$17,0^{y}$

0,06

$10,2^{\mathrm{a}}$

$12,0^{\mathrm{b}}$

0,003

$11,2^{\mathrm{a}}$

$12,6^{\mathrm{b}}$

0,01

14,2

0,12

13,5
$15,2^{\mathrm{ab}}$

$15,8^{\mathrm{b}}$

0,04

$10,9^{\mathrm{a}}$

$12,0^{\mathrm{ab}}$

$13,0^{\mathrm{b}}$

0,009

$a, b, c$ Gemiddelden met een verschillende letter binnen een rij zijn verschillend $(p<0,05)$

$-1,8^{\mathrm{x}} \quad 0,0^{\mathrm{y}} \quad-1,2^{\mathrm{xy}} \quad 0,07$

$4,1^{\mathrm{ab}}$

$3,8^{\mathrm{b}}$

0,04

$x, y$ Gemiddelden met een verschillende letter binnen een rij geven aanwijzing voor verschil $(p<0,10)$

Gewichten en spekdikten van de zeugen in de volgende worp per pariteit per voersamenstelling tijdens de lactatie.

\begin{tabular}{|c|c|c|c|c|c|c|c|}
\hline \multirow{2}{*}{ Pariteit } & \multicolumn{2}{|l|}{3} & \multicolumn{2}{|c|}{$4+5$} & \multicolumn{2}{|c|}{$6-8$} & \multirow{2}{*}{$\begin{array}{l}\text { P-waarde } \\
\text { interactie }\end{array}$} \\
\hline & zetmeel & vet & zetmeel & vet & zetmeel & vet & \\
\hline Aantal zeugen & 9 & 7 & 10 & 14 & 13 & 12 & \\
\hline \multicolumn{8}{|l|}{ Gewicht $(\mathrm{kg})$ : } \\
\hline - inzet kraamstal vorige worp & 246 & 241 & 263 & 258 & 297 & 292 & 0,99 \\
\hline - spenen vorige worp & 191 & 181 & 202 & 209 & 245 & 247 & 0,30 \\
\hline - inzet kraamstal & 257 & 249 & 269 & 273 & 298 & 309 & 0,33 \\
\hline - spenen op dag 27 & 217 & 202 & 228 & 232 & 259 & 267 & 0,14 \\
\hline \multicolumn{8}{|l|}{ Gewichtstoename (kg): } \\
\hline $\begin{array}{l}\text { - inzet kraamstal tot inzet } \\
\text { kraamstal }\end{array}$ & 11,4 & 7,5 & 6,0 & 14,9 & 1,5 & 16,3 & 0,27 \\
\hline - spenen tot inzet kraamstal & 66,6 & 68,2 & 67,4 & 63,4 & 53,0 & 61,9 & 0,27 \\
\hline
\end{tabular}




\begin{tabular}{lccccccc}
\hline Spekdikte $(\mathrm{mm})$ : & & & & & & & \\
- inzet kraamstal vorige worp & 16,4 & 14,9 & 15,6 & 14,9 & 17,6 & 16,5 & 0,88 \\
- spenen vorige worp & 10,4 & 9,2 & 10,3 & 10,1 & 12,3 & 11,8 & 0,75 \\
- dag 28 dracht & 11,0 & 10,3 & 11,3 & 11,1 & 12,7 & 12,6 & 0,87 \\
- dag 77 dracht & 13,0 & 12,4 & 14,0 & 13,0 & 14,1 & 14,3 & 0,68 \\
- inzet kraamstal & 14,1 & 13,7 & 15,4 & 15,1 & 15,3 & 16,4 & 0,50 \\
- spenen op dag 27 & 11,1 & 10,6 & 12,2 & 11,8 & 12,9 & 13,2 & 0,77 \\
Spekdiktetoename (mm): & & & & & & & \\
- inzet kraamstal tot inzet & $-2,3$ & $-1,3$ & $-0,2$ & 0,2 & $-2,3$ & $-0,1$ & 0,42 \\
kraamstal & & & & & & & \\
- spenen tot inzet kraamstal & 3,7 & 4,5 & 5,1 & 5,0 & 3,0 & 4,6 & 0,21 \\
\hline
\end{tabular}

Gewichten en spekdikten van de zeugen in de volgende worp per pariteit per voerniveau in de dracht.

\begin{tabular}{|c|c|c|c|c|c|c|c|}
\hline \multirow{2}{*}{$\begin{array}{l}\text { Pariteit } \\
\text { Voerniveau }\end{array}$} & \multicolumn{2}{|r|}{3} & \multicolumn{2}{|r|}{$4+5$} & \multicolumn{2}{|r|}{$6-8$} & \multirow[t]{2}{*}{$\begin{array}{l}\text { P-waarde } \\
\text { interactie }\end{array}$} \\
\hline & hoog & standaard & hoog & standaard & hoog & standaard & \\
\hline Aantal zeugen & 9 & 7 & 12 & 12 & 16 & 9 & \\
\hline \multicolumn{8}{|l|}{ Gewicht $(\mathrm{kg})$ : } \\
\hline $\begin{array}{l}\text { - inzet kraamstal vorige } \\
\text { worp }\end{array}$ & 243 & 244 & 261 & 260 & 296 & 293 & 0,97 \\
\hline - spenen vorige worp & 183 & 188 & 207 & 204 & 244 & 248 & 0,74 \\
\hline - inzet kraamstal & 256 & 250 & 275 & 267 & 306 & 300 & 0,98 \\
\hline - spenen op dag 27 & 205 & 215 & 231 & 229 & 263 & 263 & 0,57 \\
\hline $\begin{array}{l}\text { Gewichtstoename }(\mathrm{kg}) \text { : } \\
\text { - inzet kraamstal tot } \\
\text { inzet kraamstal }\end{array}$ & 12,2 & 6,6 & 13,9 & 6,9 & 10,7 & 7,1 & 0,95 \\
\hline $\begin{array}{l}\text { - spenen tot inzet } \\
\text { kraamstal }\end{array}$ & 72,9 & 61,9 & 68,1 & 62,7 & 62,4 & 52,5 & 0,77 \\
\hline \multicolumn{8}{|l|}{ Spekdikte $(\mathrm{mm})$ : } \\
\hline $\begin{array}{l}\text { - inzet kraamstal vorige } \\
\text { worp }\end{array}$ & 15,5 & 15,8 & 15,0 & 15,5 & 16,9 & 17,2 & 0,97 \\
\hline - spenen vorige worp & 9,6 & 10,0 & 10,4 & 10,0 & 11,8 & 12,3 & 0,78 \\
\hline - dag 28 dracht & 10,6 & 10,8 & 11,5 & 10,9 & 12,9 & 12,3 & 0,81 \\
\hline - dag 77 dracht & 13,0 & 12,4 & 13,9 & 13,1 & 14,1 & 14,2 & 0,79 \\
\hline - inzet kraamstal & 13,8 & 14,0 & 15,1 & 15,3 & 16,5 & 15,2 & 0,50 \\
\hline - spenen op dag 27 & 10,5 & 11,3 & 12,0 & 12,0 & 13,3 & 12,8 & 0,68 \\
\hline \multicolumn{8}{|l|}{ Spekdiktetoename $(\mathrm{mm})$ : } \\
\hline $\begin{array}{l}\text { - inzet kraamstal tot } \\
\text { inzet kraamstal }\end{array}$ & $-1,8$ & $-1,8$ & 0,2 & $-0,2$ & $-0,5$ & $-2,0$ & 0,59 \\
\hline $\begin{array}{l}\text { - spenen tot inzet } \\
\text { kraamstal }\end{array}$ & $4,2^{x y}$ & $4,0^{x y}$ & $4,8^{y}$ & $5,3^{y}$ & $4,7^{y}$ & $2,9^{y}$ & 0,06 \\
\hline
\end{tabular}

$x, y$ Gemiddelden met een verschillende letter binnen een rij geven aanwijzing voor verschil $(p<0,10)$ 


\section{Bijlage 8 Productieresultaten per pariteit in de volgende worp}

Productieresultaten van de zeugen in de volgende worp per pariteit; in de voorgaande lactatie zijn de zeugen geïnsemineerd tijdens een 6-weekse lactatie en kregen ze tijdens de laatste 8 dagen van de lactatie een zetmeelrijk of vetrijk voer verstrekt; na spenen werden de zeugen tot 34 dagen dracht volgens een hoog $(3,5 \mathrm{~kg} / \mathrm{d})$ of standaard $(2,8 \mathrm{~kg} / \mathrm{d})$ voerschema gevoerd.

\begin{tabular}{lcccc}
\hline Pariteit & 3 & $4+5$ & $6-8$ & P-waarde \\
\hline Aantal worpen & 16 & 24 & 25 & 0,61 \\
Totaal geboren biggen & 15,1 & 15,2 & 16,3 & 0,98 \\
Levend geboren biggen & 14,1 & 14,4 & 14,3 & 0,09 \\
Doodgeboren biggen & $1,0^{\mathrm{x}}$ & $0,8^{\mathrm{x}}$ & $2,0^{\mathrm{y}}$ & 0,39 \\
Geboortegewicht levend geboren biggen $(\mathrm{kg})$ & 1,26 & 1,35 & 1,33 & 0 \\
\hline
\end{tabular}

$x, y$ Gemiddelden met een verschillende letter binnen een rij geven aanwijzing voor verschil $(p<0,10)$

Productieresultaten in de volgende worp per pariteit per voersamenstelling tijdens de lactatie.

\begin{tabular}{|c|c|c|c|c|c|c|c|}
\hline \multirow{2}{*}{$\begin{array}{l}\text { Pariteit } \\
\text { Voersamenstelling }\end{array}$} & \multicolumn{2}{|l|}{3} & \multicolumn{2}{|c|}{$4+5$} & \multicolumn{2}{|c|}{$6-8$} & \multirow{2}{*}{$\begin{array}{l}\text { P-waarde } \\
\text { interactie }\end{array}$} \\
\hline & zetmeel & vet & zetmeel & vet & zetmeel & vet & \\
\hline Aantal worpen & 9 & 7 & 10 & 14 & 13 & 12 & \\
\hline Totaal geboren biggen & 15,7 & 14,4 & 14,4 & 15,9 & 16,5 & 16,1 & 0,57 \\
\hline Levend geboren biggen & 14,7 & 13,5 & 13,8 & 15,0 & 13,9 & 14,7 & 0,64 \\
\hline Doodgeboren biggen & 1,0 & 0,9 & 0,6 & 0,9 & 2,6 & 1,4 & 0,43 \\
\hline $\begin{array}{l}\text { Geboortegewicht levend } \\
\text { geboren biggen }(\mathrm{kg})\end{array}$ & 1,26 & 1,27 & 1,44 & 1,26 & 1,37 & 1,30 & 0,34 \\
\hline
\end{tabular}

Productieresultaten in de volgende worp per pariteit per voerniveau in de dracht.

\begin{tabular}{lccccccc}
\hline Pariteit & \multicolumn{3}{c}{3} & \multicolumn{2}{c}{$4+5$} & & $\begin{array}{c}\text { P-waarde } \\
\text { interactie }\end{array}$ \\
\hline Voerniveau & hoog & standaard & hoog & standaard & hoog & standaard \\
\hline Aantal worpen & 9 & 7 & 12 & 12 & 16 & 9 & 0,83 \\
Totaal geboren biggen & 15,0 & 15,1 & 15,9 & 14,4 & 17,0 & 15,6 & 0,77 \\
Levend geboren biggen & 13,7 & 14,5 & 14,9 & 13,8 & 14,8 & 13,8 & 0,98 \\
Doodgeboren biggen & 1,3 & 0,6 & 1,0 & 0,6 & 2,2 & 1,8 & 0,07 \\
Geboortegewicht levend & $1,33^{x y}$ & $1,20^{x}$ & $1,40^{y}$ & $1,29^{x y}$ & $1,27^{x y}$ & $1,39^{x y}$ & \\
geboren biggen $(\mathrm{kg})$ & & & & & & & \\
\hline
\end{tabular}

$x, y$ Gemiddelden met een verschillende letter binnen een rij geven aanwijzing voor verschil $(p<0,10)$ 


\section{Bijlage 9 Relaties}

Relatie gewichtsafname zeug tijdens de laatste 8 dagen van de 6-weekse zoogperiode en groei van de biggen in deze periode $(p=0,07)$

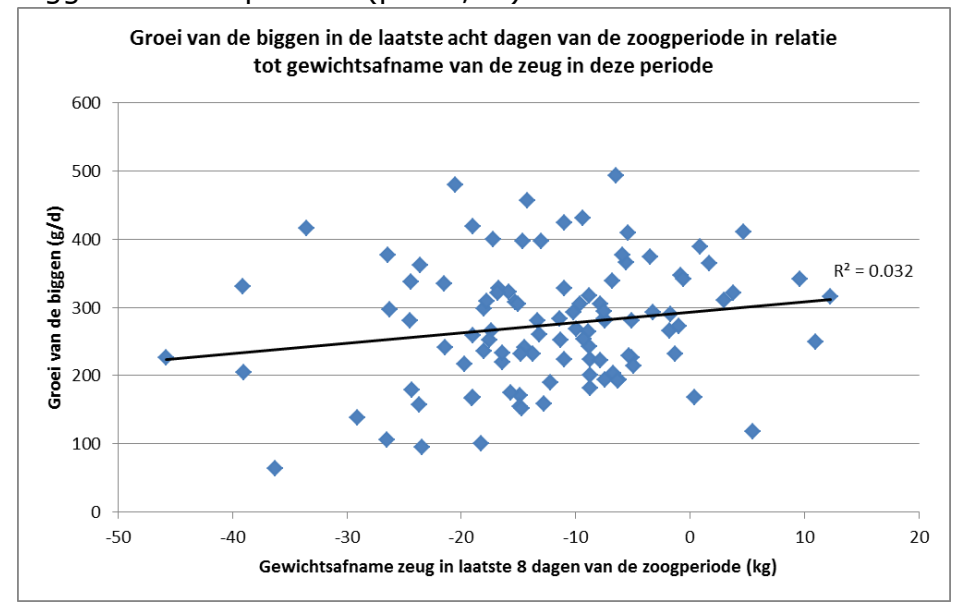

Relatie spekdikte bij start voerbehandeling op dag 34 na werpen en voeropname van de biggen tijdens de laatste 8 dagen van de 6-weekse zoogperiode $(p=0,02)$

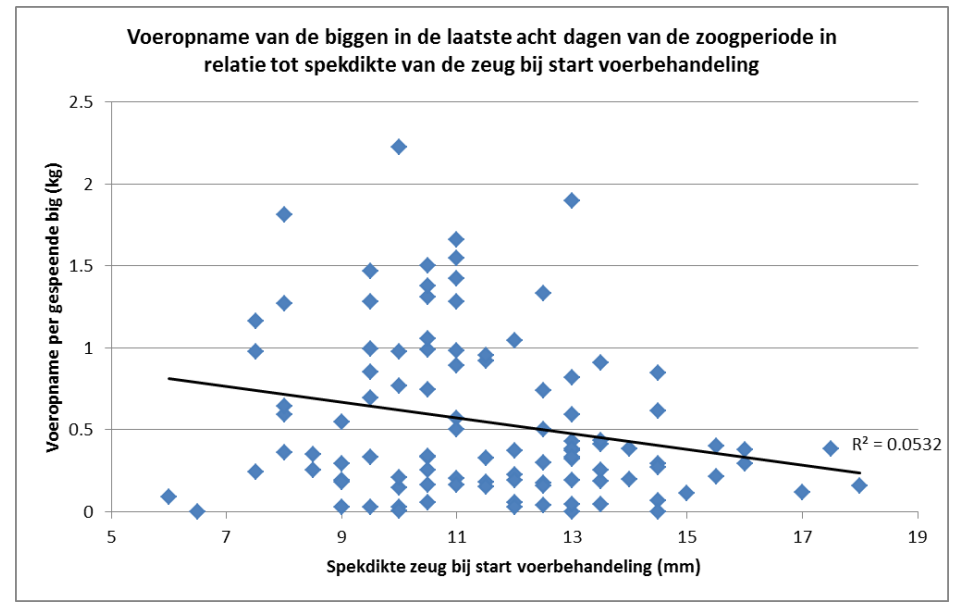

Relatie spekdikte afname zeug en aantal levend geboren biggen in de volgende worp $(p=0,04)$

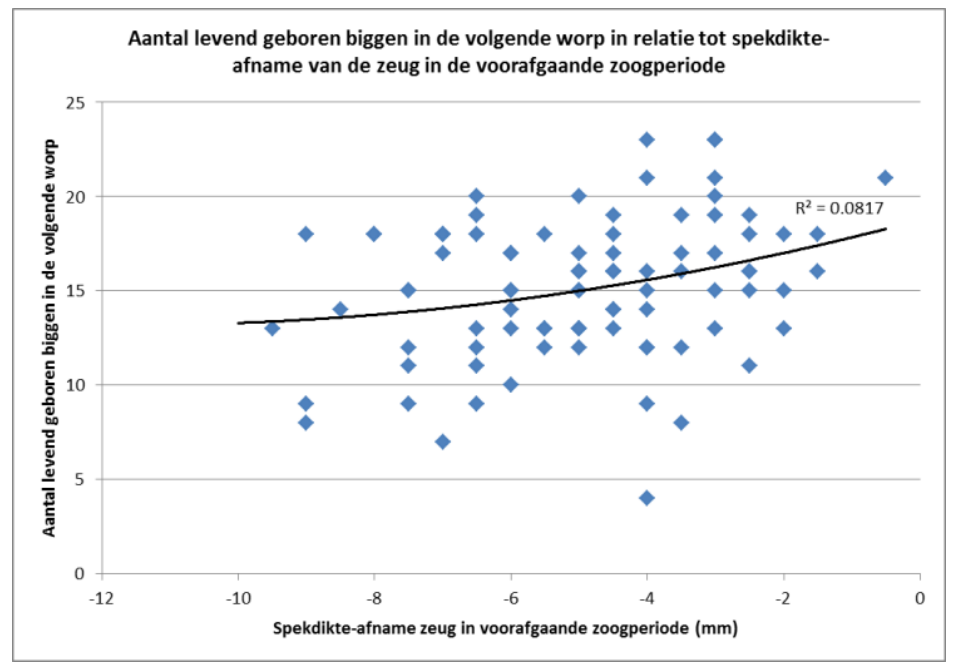



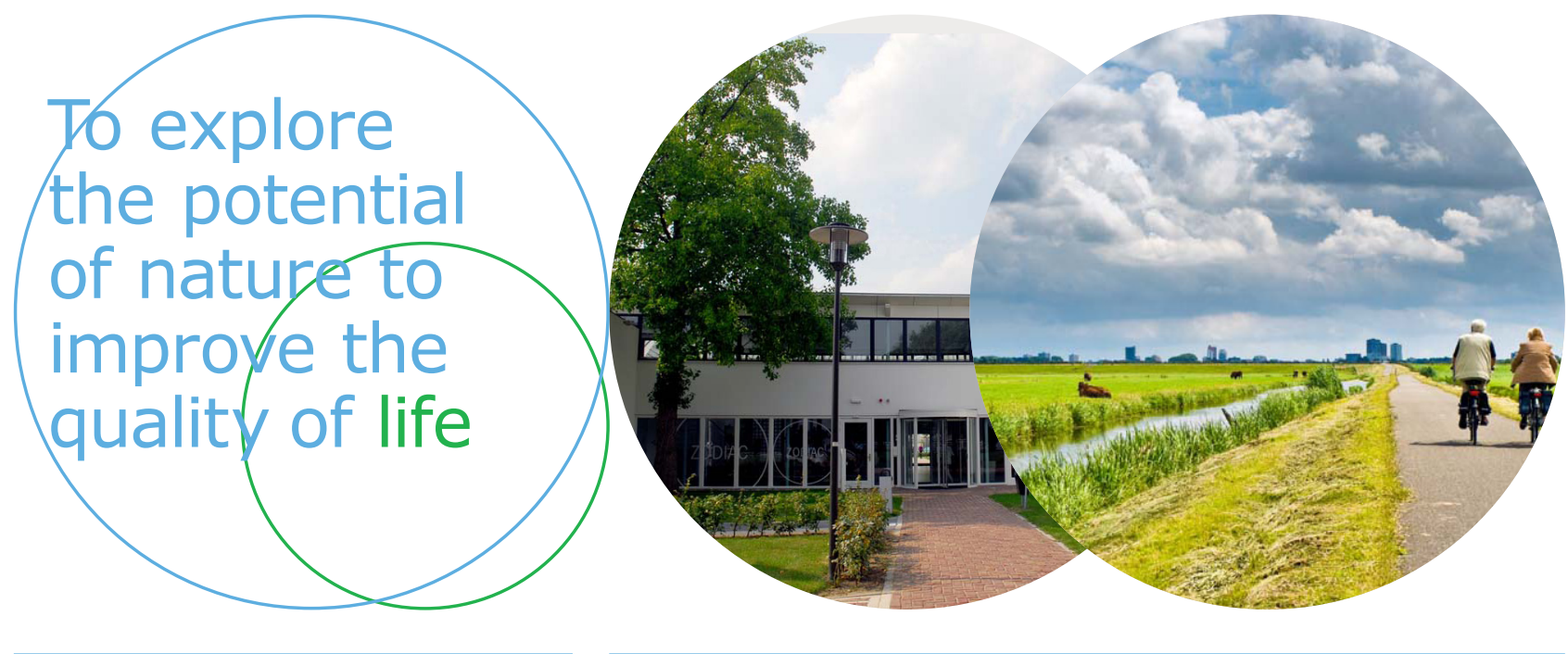

Wageningen UR Livestock Research Postbus 338

$6700 \mathrm{AH}$ Wageningen

T 0317483953

E info.livestockresearch@wur.nl www.wageningenUR.nl/livestockresearch

http://dx.doi.org/10.18174/384162
Wageningen UR Livestock Research ontwikkelt kennis voor een zorgvuldige en renderende veehouderij, vertaalt deze naar praktijkgerichte oplossingen en innovaties, en zorgt voor doorstroming van deze kennis. Onze wetenschappelijke kennis op het gebied van veehouderijsystemen en van voeding, genetica, welzijn en milieu-impact van landbouwhuisdieren integreren we, samen met onze klanten, tot veehouderijconcepten voor de $21 \mathrm{e}$ eeuw.

De missie van Wageningen UR (University \& Research centre) is 'To explore the potential of nature to improve the quality of life'. Binnen Wageningen UR bundelen 9 gespecialiseerde onderzoeksinstituten van stichting DLO en Wageningen University hun krachten om bij te dragen aan de oplossing van belangrijke vragen in het domein van gezonde voeding en leefomgeving. Met ongeveer 30 vestigingen, 6.000 medewerkers en 10.000 studenten behoort Wageningen UR wereldwijd tot de aansprekende kennisinstellingen binnen haar domein. De integrale benadering van de vraagstukken en de samenwerking tussen verschillende disciplines vormen het hart van de unieke Wageningen aanpak. 